December 2006

\title{
"Native Christians Massacred": The Ottoman Genocide of the Assyrians during World War I
}

Hannibal Travis

Follow this and additional works at: https://digitalcommons.usf.edu/gsp

\section{Recommended Citation}

Travis, Hannibal (2006) "'Native Christians Massacred": The Ottoman Genocide of the Assyrians during World War I," Genocide Studies and Prevention: An International Journal: Vol. 1: Iss. 3: Article 8.

Available at: https://digitalcommons.usf.edu/gsp/vol1/iss3/8

This Articles is brought to you for free and open access by the Open Access Journals at Digital Commons @ University of South Florida. It has been accepted for inclusion in Genocide Studies and Prevention: An International Journal by an authorized editor of Digital Commons @ University of South Florida. For more information, please contact digitalcommons@usf.edu. 


\title{
"Native Christians Massacred": The Ottoman Genocide of the Assyrians during World War I
}

\author{
Hannibal Travis \\ Florida International University College of Law
}

\begin{abstract}
The Ottoman Empire's widespread persecution of Assyrian civilians during World War I constituted a form of genocide, the present-day term for an attempt to destroy a national, ethnic, or religious group, in whole or in part. Ottoman soldiers and their Kurdish and Persian militia partners subjected hundreds of thousands of Assyrians to a deliberate and systematic campaign of massacre, torture, abduction, deportation, impoverishment, and cultural and ethnic destruction. Established principles of international law outlawed this war of extermination against Ottoman Christian civilians before it was embarked upon, and ample evidence of genocidal intent has surfaced in the form of admissions by Ottoman officials. Nevertheless, the international community has been hesitant to recognize the Assyrian experience as a form of genocide. The Assyrian genocide is indistinguishable in principle from its Armenian counterpart, however, and its recognition by scholars and the international community may assist in the resettlement and relief of the Assyrian remnant, currently fleeing by the thousands from its homelands in Iraq.
\end{abstract}

\section{Introduction}

Since the invasion of Iraq by a coalition of democratic nations in 2003, the plight of the Christians of that nation has captured the world's attention in a manner not seen since World War I. What was a steady flow of Assyrian refugees out of Iraq, after the Gulf War and the comprehensive economic sanctions of the 1990s, has accelerated since the 2003 war into a torrent of refugee flight into western Asia, Europe, the United States, and Australia. The international press could no longer ignore the Assyrians' increasingly desperate straits. ${ }^{1}$

During and after World War I, newspapers in London, Paris, New York, and Los Angeles regularly reported on the desperate straits imposed on Assyrians, Chaldeans, Nestorians, and Syriac Christians in the Ottoman Empire. ${ }^{2}$ Like the Armenians, the Assyrians living in Mesopotamia, Persia, Azerbaijan, and Turkey became victims of a genocidal "holy war" declared by the Ottoman Sultan and carried out by the Young Turk regime of Enver Pasha. That this war against the indigenous Christians of the Ottoman Empire was genocidal in character is manifest not only from the admissions of Ottoman and Turkish officials at the highest levels of government but also from those of their German allies in World War I, American and British officials, legions of foreign journalists and missionaries, and, of course, the countless civilian victims of the war's massacres and deportations.

As described by those who lived them, the events of 1915-1916 in the Ottoman Empire were clearly a form of genocide, the contemporary term for any attempt to destroy a national, ethnic, or religious group in whole or in part. As in other recognized genocides, the Ottomans and their local allies, the Kurds and 
Persians, demonstrated a pattern of deliberate and systematic targeting of Christians as such, including Assyrians, for murder, maiming, enslavement, rape, dispossession, impoverishment, and cultural and ethnic destruction. Nevertheless, governments and historians have not been as willing to recognize the Assyrian experience during and after World War I as a form of genocide, or even to acknowledge the existence and criminality of the Ottoman atrocities against Assyrians, as to give such recognition to the Ottoman genocide of the Armenians. Generally speaking, recognition of the latter by both governments and historians has been more rapid, official, and detailed.

This article will argue that the hesitation to recognize the Assyrian genocide is unjustified, for the evidence is overwhelming that Turks and their Kurdish allies massacred tens, and more likely hundreds, of thousands of Assyrians in order to exterminate the Christian population; raped and enslaved hundreds, and more likely thousands, of Assyrian women in a systematic fashion; and deported the Assyrians en masse from their ancestral lands under conditions that led to famine and widespread death. I will maintain that the more rapid legal recognition and establishment of compensation mechanisms for the Ottoman genocide of Armenians are attributable to the larger numbers of Armenian victims and survivors, as well as to more copious evidence of an intention on the part of the Young Turks to wipe out the Armenian people. In conclusion, I will contend that the legal and historical recognition of the Assyrian genocide at the hands of the Ottomans is vital to focus the world's attention on the Assyrian remnant in Iraq. That remnant has been dispersed by more than a century of massacre, discrimination, and religious persecution into non-viable communities that must be restored to their homelands, and to their rights of self-determination, or they will scatter around the globe, refused asylum too often.

\section{The Assyrians and the Turks in Mesopotamia and Persia}

The Assyrian homeland is in northern Mesopotamia, present-day Iraq, where the ancient cities of Assur and Nineveh were built. ${ }^{3}$ For 300 years, Assyrian kings ruled the largest empire the world had yet known. ${ }^{4}$ The Assyrian Church of the East records that the Apostle Thomas himself converted the Assyrians to Christianity within a generation after the death of Christ." Christianity was "well established and organized" in Mesopotamia by the third century CE. ${ }^{6}$

The (Assyrian) Church of the East became independent from the Roman Catholic Church in the fifth century CE, after the Patriarch of Constantinople, Nestorius, refused to assent to the concept of theotokos, or the idea that Mary was the mother of God, and not merely of Jesus' human form. ${ }^{7}$ By the sixth century CE, the Church of the East had preached Christianity to the Persians, Medes, Huns, and Bactrians-indeed, throughout the Middle East, from the Persian Gulf to the Caspian Sea, and even as far as India, Tibet, China, Korea, and Japan. ${ }^{8}$ One millennium later, the ethnic Assyrians of Mesopotamia and Persia remained Christians, and some of them had entered into communion with Rome by founding the Chaldean Catholic Church. ${ }^{9}$

Although some authors doubt that an Assyrian people could have survived from $600 \mathrm{BCE}$ to the nineteenth century, many of the factors that justify recognizing Armenians, Jews, and other groups as continuously existing since ancient times also apply to the Assyrians: common patterns of worship, consistent self-identification, and genetic continuity. ${ }^{10}$ As the early Christian church was growing and evangelizing distant lands, Assyrian identity survived the destruction of Nineveh. Assyrians continued to practice their ancient religion and inhabited their ancient 
capital of Assur, rebuilt in a new style. ${ }^{11}$ The ancient Assyrian capital of Nineveh was a Nestorian bishopric at the time of the Islamic conquest of Iraq, and Nestorian "Syrian"-or, more likely, Assyrian-Christians living under the Abbasid Caliphs are credited with translating many Greek scientific and philosophical works into Arabic. ${ }^{12}$ The modern Assyrians of Iraq and Persia have had such ancient Assyrian names as Sargon and Sennacherib since the earliest European contact with them. ${ }^{13}$ The name "Assyria" was also consistently applied to the area around the ancient Assyrian capital of Nineveh, and the Christians of Iraq reaffirmed their Assyrian identity from the earliest French and British contact. ${ }^{14}$ Although genetic testing of the Assyrians is just getting under way, such testing as has been done supports the idea that Assyrians very rarely intermarried with the surrounding population, at least in Persia. ${ }^{15}$

The Assyrians have been a people without a state for more than two millennia, since the fall of the empire and sack of Nineveh in 612 BCE. ${ }^{16}$ With the Arab conquests of Mesopotamia and neighboring Persia and Syria, as well as Armenia, Egypt, and the Levant, the Eastern Christian peoples fell to a subordinate status. ${ }^{17}$ Arab officials decreed the destruction of many churches, the cessation of Christian religious services, the deportation of Christians from the land, the expropriation of their property, and the executions of those who resisted. ${ }^{18}$

For more than a thousand years before Mesopotamia and Persia fell under Turkish domination, Turks had begun infiltrating Mesopotamia from Central Asia, as nomads and imported slaves. ${ }^{19}$ The Seljuk Turks seized power from the Baghdad caliphs in the eleventh century, only to be overthrown by the murderous Mongol hordes of Genghis Khan, Hulagu Khan, and Timur the Lame. ${ }^{20}$ These forces massacred thousands of people and destroyed many ancient cities, claiming countless Assyrian churches and faithful and driving the Assyrian community into the nearly inhospitable Hakkari mountains of Kurdistan. ${ }^{21}$ The Ottoman Turks re-conquered Mesopotamia in the sixteenth century and ruled it, with substantial periods of Safavid Persian and Mamluk Georgian rule intervening, until World War I. ${ }^{22}$

\section{The Nineteenth-Century Massacres of the Ottoman Christians}

Historians record that the first massacre of Assyrians in modern times took place in the 1840s, in northern Mesopotamia. The Ottoman Turks allowed the Assyrians to be massacred by the Kurdish chieftain Badr Khan Bey, who summoned the surrounding Muslim population to a "Holy War," killing 10,000 Assyrians, enslaving many women and children, and ravaging villages. ${ }^{23}$ Turkish soldiers and their Kurdish allies murdered the Christians of half a dozen Mesopotamian Christian villages; ${ }^{24}$ the surviving women and children were kidnapped and enslaved. ${ }^{25}$ Slavery was a common fate of Ottoman Christians in the nineteenth century. ${ }^{26}$

By the turn of the twentieth century, the Ottoman Sultan Abdul Hamid II had created an irregular force of pro-government Kurdish horsemen called the Hamidiye. ${ }^{27}$ The Hamidiye massacred and made refugees of the restive Assyrian and Armenian subjects of the Ottoman Empire, as the contemporary Arab Janjaweed in Sudan have done to the indigenous Africans in Darfur. ${ }^{28}$ Famine, ravaged towns and villages, and extermination of the Christian population were the legacies of the Hamidiye horsemen. ${ }^{29}$ The Kurds organized into the Hamidiye "received assurances that they [would] not be called to answer before the tribunals for any acts of oppression committed against Christians."30 
Ottoman forces killed tens of thousands of defenseless Christians in the capital, Constantinople, and in the "provincial towns of the Empire." ${ }^{11}$ In 1895, the French vice-consul for the southeastern Anatolian city of Diyarbekir reported a campaign of terror against the Armenians and Assyrians. His description reminds us of Kristallnacht in Nazi Germany: hundreds of Christians were murdered, hundreds of Christian homes ransacked, and hundreds of Christian-owned shops looted and burned. ${ }^{32}$ In nearby Urfa, the Edessa of Christian learning, the pogrom launched by the Sultan led to the massacre of 3,000 women and children inside the city's cathedral. $^{33}$

The French ambassador, Paul Cambon, wrote that Asia Minor was "literally in flames," with "massacres everywhere" and Kurds and other Muslims "massacring all Christians without distinction." 34 A French vice-consul wrote to the French ambassador to Constantinople that the Ottoman government had, "for the last few years, been pursuing its goal of gradually annihilating the Christian element" by "giving the Kurdish chieftains carte blanche to do whatever they please, to enrich themselves at the Christians' expense and to satisfy their men's whims." 35 The Hamidiye, the vice-consul declaimed, was "a band of official highway robbers spreading terror throughout this vilayet [province or administrative division] and many others." 36 The "impunity they enjoy for the crimes they commit every day" was "ample proof" of an Ottoman policy of annihilating the Christians of the Empire. ${ }^{37}$

Ottoman Christians found themselves "dispersed" to other regions and living in "deplorable conditions." 38 Their religious leaders predicted that "the Christian element will slowly disappear, either by apostasy, emigration, or massacre."39 The Ottomaninstigated atrocities of the Kurdish Hamidiye prompted the leaders of the Eastern Christian denominations within the Empire to expect the "complete disappearance of the Christian element."40

The Sultan had "consenting awareness" of the massacres of the Assyrians and Armenians within his empire, an awareness of the same character used to indict heads of states and armies for war crimes and genocide. ${ }^{41}$ According to a report by the British consul, the Ottoman leadership had granted the Kurdish horsemen guarantees against prosecution for murders of the Sultan's Christian subjects. ${ }^{42}$ The massacres of Armenians and other Christians spread to Sasun in 1904, and Adana and Cilicia in 1909. ${ }^{43}$ The British and Russians threatened military intervention unless the Ottomans reformed their pattern of persecuting their Christian subjects. ${ }^{44}$ But the Sultan never implemented proposed reforms to protect minorities. ${ }^{45}$ The Ottoman Empire's campaign to exterminate its Christians had begun, as former British prime minister William Ewart Gladstone recognized in a public speech in $1896 .^{46}$

\section{Eyewitness Accounts of the Ottoman Genocide of the Assyrians during World War I}

In the second decade of the twentieth century, the Ottoman Empire suffered a string of setbacks that set its leaders on a much more violent and fanatical course. A coalition of Austrian, Greek, Bulgarian, and Serbian forces drove the Turkish occupiers out of their erstwhile imperial provinces in Europe, routing their armies and inflicting thousands of casualties. ${ }^{47}$ An ultranationalist group called the Committee of Union and Progress (CUP), or "Young Turks," emerged after 1905 and steadily gained control over the Ottoman government and legal system. ${ }^{48}$ The Young 
Turks seized power in 1913, forming a military dictatorship run by the triumvirate of Ismail Enver Pasha, minister of war; Mehmet Talât Pasha, minister of interior affairs; and Ahmet Cemal Pasha, minister of the navy. ${ }^{49}$ The Young Turks imposed "Ottomanization" and began conscripting Christians into the army for the first time in many years, driving many Assyrians and other Christians to flee the country. 50

On 14 November 1914, less than two weeks after the Ottoman Empire declared war on the Entente (Great Britain, France, and Russia), the Sultan, still acting as a figurehead for the Young Turk regime, declared a jihad or holy war "against the enemies of Islam, who have proven their hostility by their attacks on the Caliphate."51 The next day, a key CUP official led a march through Istanbul "meant to demonstrate the people's agreement with the Sultan's declaration of holy war against the enemies of Islam."52 The Sheikh al-Islam, a CUP appointee and the highest religious authority in the Ottoman regime, endorsed the declaration of jihad and proclaimed it in print; violence against Christian Armenians quickly followed. ${ }^{53}$ These declarations of jihad "incited wrath toward Christian minorities in the Ottoman lands, and...later facilitated the government's program of Genocide against the Armenians"-and, as it happened, the Assyrians. ${ }^{54}$

The Turks, reinforced by Kurdish irregulars, invaded Russian-controlled northern Persia in the winter of 1914, and in early January 1915 they forced a Russian evacuation of the northern Persian cities of Urmia, Tabriz, Salmas, Diliman, and Gulpashan, among others. ${ }^{55}$ Kurdish irregulars would serve as important allies to the Ottoman military in World War I, as the Hamidiye contingents had done prior to the turn of the century. ${ }^{56}$

A key source of evidentiary support for the existence of the Armenian and Assyrian genocides is the famous "Blue Book" compiled by Viscount James Bryce and Arnold Toynbee in 1916, commonly known by the title under which it was released by the British Foreign Office: The Treatment of Armenians in the Ottoman Empire 1915-16. The British government commissioned Viscount Bryce and Mr. Toynbee, a young historian affiliated with Oxford University, to prepare a "general narrative" of the "accounts of massacres and deportations of the Christian population of Asiatic Turkey," accounts that had increased in "number and fullness of detail." Toynbee via the United States, then professing neutrality in World War I, from citizens of neutral countries, often American missionaries. ${ }^{58}$ More than three dozen of the reports in the Blue Book constituted official State Department records. 59

The original title of this compilation of American and European eyewitness testimony and documentation of the Armenian and Assyrian genocides was "Papers and Documents on the Treatment of Armenians and Assyrian Christians by the Turks, 1915-1916, in the Ottoman Empire and North-West Persia."60 Bryce, something of a "champion of the Ottoman Armenians," 61 had removed the reference to Assyrian Christians in the title of the Blue Book prior to its publication by Her Majesty's Stationery Office. ${ }^{62}$ The deletion of the accounts of the Assyrian massacres from the French translation of the Blue Book presented to the Paris Peace Conference of 1919-1920 further distorted the historical record. ${ }^{63}$

The Blue Book documents how, under Turkish occupation and "urged on and followed by Turkish officers and troops," the Kurds and other Muslims in and around Urmia "set to work robbing and looting, killing men and women and outraging 
the women."64 Turkish forces directly massacred the Christian population and failed to prevent many other massacres, leading to

the murder of over one thousand people-men, women, and children; the outraging of hundreds of women and girls of every age-from eight or nine years old to old age; the total robbing of about five-sixths of the Christian population; and the total destruction of about the same proportion of their houses. ${ }^{65}$

At least 4,000 perished from disease while or after being driven from their homes or lands. ${ }^{66}$ Kidnapping and sexual slavery were used to destroy the Christian community: "Over two hundred girls and women were carried off into captivity, to be forced to embrace Islam and to accept Mohammedan husbands."67

Another eyewitness account recorded in the Blue Book states that in the largest "Syrian" or Assyrian village in Urmia, ${ }^{68}$ all the men were hauled over to the cemetery to be murdered, while the "women and girls [were] treated barbarously," and sixty men were removed from the French Mission and summarily shot. ${ }^{69}$ In the Catholic Mission in Urmia, dozens of Christians, including an Episcopal bishop, "were bound together one night, taken to Gagain mountain and there shot down."70 A minister affiliated with the Church of England's mission to Assyrians reported that "those who died from the slaughter and raiding of villages numbered 6,000."71 Another report estimated 8,500 deaths in and around Urmia in five months in $1915 .^{72}$

Many other Assyrians in Persia suffered a similar fate under the Turks. In Salmas, a town in Persia inhabited by more than 2,000 Assyrians, the Turks gathered together and massacred about 800 Christians, mostly women and older men, prior to the Turkish withdrawal from the area. ${ }^{73}$ Some Christian men "were tied with their heads sticking through the rungs of a ladder and decapitated, others hacked to pieces or mutilated before death." ${ }^{74}$ In Diliman, Persia, "all the males above twelve years of age... were taken to two neighboring villages, tortured and shot." In Gulpashan, Persia, dozens of men were tied together to be shot outside the village, their "wives and daughters distributed among the Turks, Kurds, and Persian Mohammedans."76 About one-fifth of the 30,000 Assyrians living in Urmia and its surrounding villages died, and their villages were the most part torched, with their cultural property, their churches, reduced to ruin. ${ }^{77}$ These accounts from the Blue Book are corroborated by American diplomatic files, which document that

During the period of Turkish occupation [of northwestern Persia], from January 1st to May 24th [1915], all the Christian villages and all the Christians living in Moslem villages were completely looted, men were killed, women were violated and some two hundred girls taken away captive .... thousands died of disease. ${ }^{78}$

American missionary William A. Shedd reported to the US minister to Persia that one-fifth of the total population of Christians in the Urmia region had perished in the first five months or so of 1915 alone and that the vast majority of families had had all their property stolen. ${ }^{79}$

In Turkey itself, the Assyrians were caught up with the Armenians in a common genocidal campaign against Christians. Thousands of Assyrians and Chaldeans were caught up with nearly half a million Armenians in massacres, widespread assaults against woman and girls, and pillaging of immeasurable amounts of property. ${ }^{80}$ Referring to southeastern Turkey, German missionary Johannes Lepsius wrote, 
"In certain places, as in Mardin, all Christians have suffered the same fate without differentiation as to race or denomination." 81

The Blue Book reports that the governor of the vilayet of Van, Djevdet Bey, led massacres of its Christian, mostly Armenian, population. ${ }^{82}$ Another source reports that two dozen or more Assyrian and Chaldean villages in Van lost hundreds of civilians to these massacres. ${ }^{83}$ Djevdet Bey formed special divisions of Turkish troops known as "butcher battalions" (Kassab Tabouri), which massacred the men of Bitlis. ${ }^{84}$ His troops and their local allies collected all the women and the girls in an open area, systematically assaulted them, and then sold them into slavery or gave them as "gifts" to one another. ${ }^{85}$ Similarly, in Bashkala (Bachcelet), a town in Van, "many hundreds (perhaps some thousands) of Armenians and Syrians... [were] massacred."86 Armenians reported that the women and children of the Bashkala area had been either killed or forced into "a captivity worse than death." 87

The Chaldean population of Turkey generally shared the fate of the Armenians, including 8,000 Chaldeans killed in the diocese and village of Seert; nearly 4,000 killed in the city and diocese of Adana; many Chaldean families killed in the villages surrounding the diocese of Diyarbekir (save for about forty families in Diyarbekir itself); and hundreds of Chaldeans from dozens of families deported from the city of Mardin, the diocese of Jazirah, and the diocese of Amadiya. ${ }^{88}$ About 500 Christians met their end in a massacre inside a Chaldean church. ${ }^{89}$

The slaughter of Christians described in the Blue Book was not confined to Turkey or to northern Persia but extended to Mesopotamia. The Assyrians, after suffering "massacres and aggressions" instigated by Turkish officials and carried out by Kurds, ${ }^{90}$ had declared independence from the Ottomans, giving the "best of pretexts" to the Kurds to attack them "under Turkish instigation." 91 Even prior to the war, the Turks had refused to restrain Kurdish forces from slaughtering Christians and plundering their habitations. ${ }^{92}$ An American missionary reported that his countrymen "would have been ashamed not to resist under such circumstances." 93 Those Christians who could not fight back had fled to Urmia from the districts of Tergawar, Dasht, and Mergawar, which, according to Dr. Harry P. Packard of the Board of Foreign Missions of the Presbyterian Church, "had been destroyed." "94 An American missionary reported, and the US minister to Persia corroborated, that in October 1914, prior to the Assyrian declaration of independence, "mixed forces encroached upon the city of Urmia, robbing and looting two Christian villages, killing many non-combatants." 95 The news of these massacres in the northwest "and the hope of support from the Russians eventually led to the [Assyrian] patriarch officially declaring war on Turkey in the name of his nation (Millet) on May 10, 1915."96 Thus, although the Assyrians lacked the political parties and proximity to the Ottoman capital that made the Armenians a perceived threat to the Young Turks, they adopted a sympathetic position to the liberation of Eastern Christians by czarist Russia that threatened the Ottoman Empire's expansion.

In the Hakkari mountains of northern Mesopotamia, which also extend into northern Persia and southeastern Turkey, the Turks and their Kurdish allies destroyed many Christian villages and plundered the crops and goods there, condemning the Christian population to mass starvation. ${ }^{97}$ An American missionary stationed in northern Mesopotamia reported that the Kurds there "had interpreted 
the deportations of the Armenians as another decree against all Christians." 98 The Blue Book states that forty villages in one district of the Hakkari region had only seventeen survivors between them. ${ }^{99}$

When the Turks were forced out of Persia by the Russians in May [1915], the Turks turned on their own Assyrians. In mid-June... an attack was launched on the mountainous dwellings of the Assyrians, initially ... in the Hakkiari district, the seat of their spiritual leader, whose title is Mar Shimun.... The Turks tried to starve them out... [in what was] only the beginning of the upheaval, dispersion and massacre that characterized the history of the Assyrians throughout the war and into the mid-1930s. ${ }^{100}$

Assisted by Ottoman troops, Kurds entered Goele, a village of 300 Assyrian Catholic and Protestant families, and murdered the men, enslaved the women and children, and pillaged the houses in the village. ${ }^{101}$ In another Assyrian village of fifty houses, Kurds attacked and killed the entire defenseless population. ${ }^{102}$ Johannes Lepsius reported a massacre of 250 Chaldeans in Jazirah (Djesire), in northwestern Mesopotamia. ${ }^{103}$

By the summer of 1915 the Kurds had carried out the "proclamation of Jihad" and had "ravaged" Assyrian villages of Mesopotamia, driving the Assyrians into a desperate flight to Urmia. ${ }^{104}$ After the Russian revolution and the dissolution of the czarist army, the Assyrian nation embarked upon a "routed, headlong, and massacre-haunted straggle" out of northern Persia and over the mountains back into British-controlled Mesopotamia. ${ }^{105}$ In 1916, sixteen bishops of the Protestant Episcopal Church of the United States issued an appeal declaring that Assyrian refugees from the Hakkari mountains were "living in barns" and were "so lean and emaciated that death will get at them wholesale."106 "With the loss of the Hakiari region..., the Assyrians lost not only their homeland but also more than half their population .... the Apostolic Church of the East appeared to have been entirely wiped out." 107 As the Earl of Listowel, speaking in the House of Lords on 28 November 1933, stated, "the Assyrians fought on our side during the war," and made "enormous sacrifices," having "lost altogether by the end of the War about two-thirds of their total number." 108

The British accepted the "remnant" of the Assyrian population into refugee camps, only one-third having survived the depredations of the Turks and Kurds. ${ }^{109}$ After World War I, the Turks prevented these refugees from returning to the Hakkari mountains, ${ }^{110}$ and forces loyal to Mustafa Kemal "Atatürk" murdered many of the surviving Assyrian men not under British or Soviet protection; raped many young girls and sold others into harem slavery; and deported 8,000 Christians from Mesopotamia into the interior of Turkey. ${ }^{111}$ In 1925, the Turks ordered Kurdish chiefs to massacre the Assyrians; Turkish soldiers and Kurds murdered many Assyrians, raped and kidnapped women, plundered houses, and deported populations in a way that ensured many deaths from starvation and disease. ${ }^{112}$ Tens of thousands had died from "perpetual attacks on all sides from the Turks, Kurds and Persians alike" and from smallpox, other diseases, and the heat, which combined to claim children and the elderly in particular. ${ }^{113}$ Only about 20,000 Assyrians lived in Iraq by the $1940 \mathrm{~s}$, a number that was equaled or eclipsed by the number living in the Soviet Union $(20,000)$ and in Chicago $(30,000){ }^{114}$

The Turks extended their policy of exterminating the Christians of the empire to the Armenians, Greeks, Syrians, and Lebanese. More than 1.5 million Armenians perished in a premeditated campaign of disarmament, assassination of political 
and cultural leaders, massacre, systematic rape, deportation, pillage, and famine. ${ }^{115}$ According to an Associated Press report, of 500,000 Greeks deported from Thrace, in Asia Minor, an estimated 250,000, or half, died of disease and torture. ${ }^{116}$ Starting in 1910, the Ottoman Turks made about one million Greeks homeless and deported hundreds of thousands; as many as 300,000 Greeks died of hunger, disease, and the cold as a result. ${ }^{117}$ In the $1920 \mathrm{~s}$, the Turkish nationalists massacred about 200,000 more Christians, mostly Greeks, in cities such as Smyrna. Greek men became victims of murder, torture, and starvation; Greek women suffered all this and also became slaves in Muslim households; Greek children wandered the streets as orphans "half-naked and begging for bread"; and millions of dollars' worth of Greek property passed into Muslim hands. ${ }^{118}$ In Syria and Lebanon, "the young Turks purposely created a famine that achieved the death of at least 100,000 people."119

\section{Diplomatic and Journalistic Confirmation of the Assyrian Genocide}

Viscount James Bryce, former British ambassador to the United States, described Turkish crimes against Assyrians and Chaldeans during World War I as follows:

The bloodstained annals of the East contain no record of massacres more unprovoked, more widespread or more terrible than those perpetrated by the Turkish Government upon the Christians of Anatolia and Armenia in 1915. It was the sufferings of the Armenians that chiefly drew the attention of Britain and America because they were the most numerous among the ecclesiastical bodies, and the slaughter was, therefore, on a larger scale. But the minor communities, such as the Nestorian and Assyro-Chaldean churches, were equally the victims of the plan for exterminating Christianity, root and branch, although the Turks had never ventured to allege that these communities had given any ground of offense. An account of these massacres, organized and carried out with every circumstance of cruelty by Enver and Talaat, chiefs of the ruffianly gang who were then in power in Constantinople, has been given in the Blue Book, published by the British Foreign Office in 1916, and entitled "Treatment of the Armenians in the Ottoman Empire."... similar cruelties [were] perpetrated upon members of the AssyroChaldean Church in which about half of them, men, women and children, perished at the hands of Turkish murderers and robbers. ${ }^{120}$

American diplomatic and journalistic sources confirmed Ambassador Bryce's charge of an Ottoman policy to exterminate Christians other than the Armenians. According to the American ambassador to Constantinople from 1913 to 1916, Henry I. Morgenthau, widely regarded as a principal source of information on the Armenian Genocide: "The story which I have told about the Armenians I could also tell with certain modifications about the Greeks and the Syrians," as Assyrians were often known to the West, especially those adhering to the Syrian Orthodox Church. ${ }^{121}$ He added that the "Turks afterward decided to apply the same methods [of deportation and "wholesale massacre"] on a larger scale not only to the Greeks but to the Armenians, Syrians, Nestorians, and others of its subject peoples."122 In December 1918, according to the Los Angeles Times, Ambassador Morgenthau told an audience in Chicago that the Turks "have massacred fully 2,000,000 men, women, and children-Greeks, Assyrians, Armenians; fully 1,500,000 Armenians."123

The American consul in Aleppo, Syria, reported to the US secretary of state that "from Mardin the Government deported great numbers of Syrians, Catholics, Caldeans, and Protestants, and it is feared all Christians may later be included in 
the order and possibly even the Jews. They cry 'Turkey for the Moslems'..."124 An American consular agent in Urfa, southeastern Turkey, documented how, throughout the summer of 1915, thousands of Christian refugees had passed through the city, all relating the same sequence of events: the murder of all the men on the roads out their cities, the "criminal abuse[ ]" and kidnapping of the women and girls, the theft of all "money, bedding, and clothing." 125 His report adds, "The poor weak women and children died by thousands along the roads and in the khan where they were confined here."126

Another American diplomat reported that the Assyrians and Armenians of Harput, Turkey, were deported by a publicly announced order covering both groups in the summer of $1915 .^{127}$ In the context of the grinding poverty and wartime deprivations in Turkey, such deportation orders meant "a lingering and perhaps even more dreadful death for nearly every one" than a massacre, with probably less than one in 100 deportees surviving, as the American consul wrote to the US ambassador. ${ }^{128}$ The roads were already populated by roving bands of marauding Kurds ready to rob and murder the deportees. ${ }^{129}$

In July 1915, the German ambassador in Constantinople described to the German Imperial Chancellor how the Ottoman governor of Diyarbekir, Reşid Bey, had supervised the systematic extermination (systematischen Ausrottung) of the Christian population of his district, without regard to ethnicity or creed (der Rasse und der Konfession), but including in particular Chaldeans and Assyrians (non-uniate Syrians, German nicht unierten Syrer). ${ }^{130}$ The German consul in Mosul had blamed Reişd Bey for the massacre of the exclusively Chaldean population of the village of Faysh Khabour (Feihschahbur) near Jazirah (Djesireh). ${ }^{131}$ The German viceconsul in Mosul had reported in July 1915 that the Chaldean, Syrian, and Armenian men of the towns of Seert, Mardin, and Faysh Khabour had been massacred (massakriert), with 1,200 of their female relatives and children arriving or about to arrive in Mosul in "indescribable" (unbeschreiblich) conditions; the women and children were dying of hunger "daily." 132 Similarly, an October 1915 dispatch from the German consul in Syria to the German ambassador in Constantinople states,

Further evidence has been found that the measures [i.e., extermination and deportation] I described in my report dated 3 September - B.No. 1950 - which were to be taken against the Armenians in the eastern Vilayets have now become such against the Christians. The acting Syrian (Syrian Catholic) bishop told me that a total of 300 children and older women from his denomination have arrived here from Kharput, Diarbekr, Weranscheher and Mardin. The rest of the parishioners has probably been killed or kidnapped...

The Chaldeans in [Seert] (Vilayet Bitlis) and [Jazirah] (Vilayet Diarbekir) and all of the Christians in Djebel et Tor north of Mardin have been exterminated. ${ }^{133}$

A previous report from the same diplomat had declared that, in the eastern provinces of the Ottoman Empire, Assyrians and Chaldeans had "already for a long time" been reported either "killed" (getötet) or "banished" (verbannt). ${ }^{134}$

German military officers, diplomats, and civilians also witnessed the planning and execution of the genocide of Armenian, Assyrian, and Greek Christians as it unfolded. The accounts of German ambassadors and other officials dealing with the Ottoman Empire are replete with such terms as "extermination," "massacre," "destruction," "slaughter," "systematic butchery," and "murder of thousands of human beings." 135 As the Ottomans' main ally in World War I, the Germans had military officers "stationed throughout the Empire"; they trained and led 
Turkish troops, and their "military commanders and soldiers undoubtedly knew, saw, and it is alleged [indirectly] participated" in the genocide of Ottoman Christians. ${ }^{136}$ The German government officially protested the murders ongoing in the Ottoman Empire during the summer of $1915 .{ }^{137}$ German missionary Johannes Lepsius-in close contact with the German government, as reflected in its ambassadors' reports ${ }^{138}$ "produced two publications containing unique documentary material about the political links between imperial Germany and the extermination policy of the Young Turks"; a substantial portion of these accounts was devoted to the Assyrian genocide. $^{139}$ The evidence of German military and diplomatic awareness and complicity in the Ottoman genocide of Armenians and other Christians has filled an entire book. ${ }^{140}$

Numerous articles in the American press documented the genocide of Assyrians by the Turks and their Kurdish allies. By 1918, the Los Angeles Times carried the story of a Syrian, or most likely Assyrian, merchant from Urmia who stated that his city was "completely wiped out, the inhabitants massacred," 200 surrounding villages ravaged, 200,000 of his people dead, and hundreds of thousands of more starving to death in exile from their agricultural lands. ${ }^{141}$ In an article entitled "Native Christians Massacred," the Associated Press correspondent reported that in the vicinity of Urmia, "Turkish regular troops and Kurds are persecuting and massacring Assyrian Christians." ${ }^{142}$ Close to 800 were confirmed dead in Urmia, and another 2,000 had perished from disease. ${ }^{143}$ Two hundred Assyrians had been burned to death inside a church, and the Russians had discovered more than 700 bodies of massacre victims in the village of Hafdewan outside Urmia, "mostly naked and mutilated," some with gunshot wounds, others decapitated, and still others carved to pieces. ${ }^{144}$

A few days earlier, the Associated Press had relayed a report from the American consul at Tabriz stating that "the Turkish consul at Urumiah forced his way into the [American Christian] mission with a number of regular Turkish troops and removed some Assyrian Christian refugees, who were then massacred."145 Many other members of the "little tribe" of Assyrians had been enslaved by Kurds, and those "who did not escape or were made slaves, perished."146 Tens of thousands of Assyrians fled their homes for Russian or American protection; many died en route. ${ }^{147}$

Other leading British and American newspapers corroborated these accounts of the Assyrian genocide. The New York Times reported on 11 October that 12,000 Persian Christians had died of massacre, hunger, or disease; thousands of girls as young as seven had been raped or forcibly converted to Islam; 120 Christian villages had been destroyed, and three-fourths of Christian villages burned to the ground. ${ }^{148}$ The Times of London was perhaps the first widely respected publication to document the fact that 250,000 Assyrians and Chaldeans eventually died in the Ottoman genocide of Christians, ${ }^{149}$ a figure which many journalists and scholars have subsequently accepted. ${ }^{150}$ Among other violence, Turks and Kurds exterminated 12,000 Nestorian and Assyrian civilians in Urmia; huge mass graves holding up to 1,500 bodies were dug. ${ }^{151}$ The Ottomans and their allies plundered and burned about 150 Nestorian villages. ${ }^{152}$ Their Persian allies seized the opportunity to kidnap and enslave women and children and to forcibly convert them to Islam. ${ }^{153}$ The Persian governor of Urmia had steel and lime dust baked into the bread purchased by Christian missionaries tending to Assyrian refugees, so that thousands of the refugees perished from eating contaminated food before 
local doctors realized what was happening. ${ }^{154}$ About half of the Assyrian nation died of murder, disease, or exposure as refugees during the war, according to the head of the Anglican Church, which had a mission to the Assyrians. ${ }^{155}$ Famine and want were the fate of the survivors, whose homes, villages, churches, and schools had been wiped out. 156

The Washington Post reported in March 1915 that "Turkish regular troops and Kurds are persecuting and massacring Assyrian Christians."157 According to a letter from an American eyewitness, many of the thousands of Christian refugees in Urmia were "murdered in cold blood and with cruel tortures by the Kurds," with "women and children carried off" into slavery. ${ }^{158}$ In the village of Diza, south of Urmia, Kurdish forces had buried 3,000 Christians up to their chins, riding on horseback over and crushing the skulls of those who survived the first day of this ordeal. ${ }^{159}$ The Post also described how rampaging Kurds, spurred on by the Ottoman Empire's declaration of jihad the previous winter, exterminated the local population of Christians unable to flee because they were too old, sick, or incapacitated. ${ }^{160}$ The Kurds carried flags proclaiming the "holy war." 161 As thousands of Assyrians fled Urmia through the snowy fields to avoid bands of Kurds on the roads, the men were massacred and many girls as young as seven or eight years old "were openly assaulted." 162 In Gulpashan, Kurds tore sixty-five Christian men out of missions, to which they had fled for safety, and hanged them. ${ }^{163}$

According to one American citizen engaged in missionary work in Persia, Turks and Kurds killed nearly every Assyrian Christian they found in the town of Kochanis, on Turkish territory, and in the Christian villages and towns in the surrounding area, and destroyed most or all of the churches and religious buildings. ${ }^{164}$ This account adds that by October 1914, the Turkish government had impelled an organized army of Kurds to "expel[ ] several thousand Christians" from Turkish villages adjoining Persia and to "plunder and burn the Christian villages" in Persia adjoining eastern Turkey. ${ }^{165}$ On the road north to Russia, this missionary and another eyewitness saw thousands of Christians starving to death in the fields, children dying by the hundreds, as well as dozens of abandoned orphans. ${ }^{166}$

These diplomatic and journalistic accounts, as well as the accounts collected in the Blue Book, establish a series of critical facts about the Ottoman genocide of the Assyrians. First, the Turks and their Kurdish allies massacred untold thousands of Assyrians as part of a campaign to, in Ambassador Bryce's words, "exterminate[ ] Christianity, root and branch," in the empire. Second, reputable publications such as the Times of London and the Los Angeles Times confirm that 200,000 to 250,000 Assyrians and Chaldeans lost their lives in the Ottoman Christian genocide. Third, the rape, kidnapping, and enslavement of Assyrian women were systematic and empire-wide, rather than being the fault of a few scattered criminals or unruly mobs. Fourth, the Assyrians were "equally" (in the words of Ambassador Bryce) and by the "same methods" (in the words of Ambassador Morgenthau) subject to the Ottoman Turkish plan to wipe out the Armenian people. Fifth, the Turks deported the Assyrians en masse from their ancestral lands, confiscating thousands of homes and other property that would be of an inestimably large value today (a single apartment in present-day Turkey may be worth more than US\$100,000, while a single villa may be worth more than US\$200,000). ${ }^{167}$ Finally, this pattern of deportations and denial of housing caused thousands of Assyrians to die of other political and criminal violence, as well as of hunger, disease, exhaustion, and exposure to the elements. 


\section{Genocide as a Crime by World War I}

The present-day Republic of Turkey, as well as its defenders and certain scholars, concedes that killings or even massacres of Christians took place within the Ottoman Empire during World War I but rejects the notion that these massacres fit the technical legal definition of genocide. To start with, the Turks make the technical legal argument that genocide was not a crime at all in 1915 or 1916 . As the Web site of the Turkish government points out, the term "genocide" was not invented until 1944, and the crime was not definitively codified into law until 1948, with the UN Convention on the Prevention and Punishment of the Crime of Genocide (UNCG). ${ }^{168}$

The same Web site also reproduces, with apparent approval, an account of the "relocation" of the Armenians during World War I, which argues that the only evidence of a campaign of destruction against the Armenians was "wartime propaganda" produced by Britain and America. ${ }^{169}$ According to this account, all that happened was that when the government "relocated" Armenians living in the "war zone," the "security measures were inadequate," leading to repeated attacks on convoys "by Kurd, Circassian[,] vindictive Armenian, Turkish and Muslim people on the way." 170 The number of deaths due to such attacks, however, was "very low," even though just one Ottoman document records a massacre of 500 people. ${ }^{171}$ The Armenians themselves triggered these relocations, the story goes, by their rebelliousness and alliance with Russia, "not their ethnic or religious identity."172 Britain's Foreign and Commonwealth Office appears to concede the general thrust of Turkey's claims, calling the Armenian massacres a "terrible episode" but not "genocide." "173

These responses by the Turkish and British governments to the evidence of an Ottoman genocide of Christians warrant careful review. Their arguments raise several important questions, including (1) whether any laws criminalizing genocide were in existence during World War I, (2) whether there is any evidence of genocide aside from the "wartime propaganda" of Britain and America, and (3) whether the evidence indicates the requisite intention on the part of the Ottoman government to attempt to wipe out a group or groups of people.

To start with, if the Ottoman Empire committed genocide against its Christian population during World War I, this conduct was certainly criminal, as the Turks themselves admitted. International customary law recognized genocide as a crime prior to its incorporation into the UNCG of 1948, which defines "genocide" as killing, wounding, starving, or sterilizing members of a group "with intent to destroy, in whole or in part, [the] national, ethnical, racial, or religious group."174 The signatories to the UNCG itself recognized that genocide was already a crime by adopting language providing that "that at all periods of history genocide has inflicted great losses on humanity" and that they merely "confirm[ed]" its criminality, whether committed during war or in peacetime. ${ }^{175}$ The Nuremberg tribunal had already indicted high Nazi officials for

\footnotetext{
deliberate and systematic genocide, viz., the extermination of racial and national groups, against the civilian populations of certain occupied territories in order to destroy particular races and classes of people and national, racial, or religious groups, particularly Jews, Poles, and Gypsies and others. ${ }^{176}$
}

As the International Court of Justice has held, the "principles underlying the [Genocide] Convention are recognised by civilised nations as binding on States even without any conventional [i.e., treaty] obligation."177 Genocide is therefore, 
as a UN report has described it, a recent term for "an old crime." ${ }^{178}$ In addition to international treaties such as the UNCG, international law acknowledges the binding character of general practices and principles of law adopted by civilized nations, as illustrated by national and international judicial decisions and the teachings of experts on international law. ${ }^{179}$

Massacring civilians, as the Ottomans did in World War I, had been recognized as a war crime for centuries and had formed the basis for historic national and international criminal tribunals. ${ }^{180}$ By the first decade of the twentieth century, international treaty law specifically prohibited wartime violations against "the lives of persons," "family honour and rights," and "private property as well as religious convictions and practice."181 His Majesty the Emperor of the Ottomans was among the signatories to this treaty, and thus agreed to its preamble, which declared that, in cases not specifically provided for, "the law of nations" and "the laws of humanity" protect the inhabitants of war zones. ${ }^{182}$ As Nuremberg established, violations of this treaty, known as the Hague Convention Respecting the Laws and Customs of War on Land, were recognized as crimes from 1907 on. ${ }^{183}$

With international customary law on their side, Britain, France, and Russia, the Entente powers, issued a joint declaration in May 1915 characterizing the "connivance and often assistance of Ottoman authorities" in massacres of Armenians over the previous month as "new crimes of Turkey against humanity and civilization."184 By that declaration the Entente announced publicly "that they [would] hold personally responsible... all members of the Ottoman government and those of their agents who are implicated in such massacres." 185 The declaration recognized the Ottoman authorities' prosecution of the war as criminal and constituted "a public and joint commitment to prosecute after the war those responsible for the crimes perpetrated."186

After losing the war, Turkey commenced its own prosecutions of those responsible. An interim Ottoman government tried and convicted ministers Enver, Talât, and Cemal of widespread massacres, war crimes, and atrocities and sentenced them to death in absentia. ${ }^{187}$ The court-martial concluded that

all the testimony and documents show that... bands of brigands were formed for the sole purpose of massacring and destroying the caravans of the (Armenian) deportees. It is fully proven that these massacres were taking place on the immediate orders and full knowledge of Talat, Enver, and Cemal. ${ }^{188}$

As the New York Times reported in mid-July 1919, the triumvirate were "condemned to death" by the court-martial "for joining in the war and for the Armenian, Greek, and Syrian atrocities and deportations."189 A Turkish tribunal found that the orders for the Armenian massacres in particular had issued directly from Istanbul. ${ }^{190}$ The founder of modern Turkey, Mustafa Kemal "Atatürk," later captured the sentiments in Turkey that led to the trials of those Young Turks responsible for the Ottoman genocide of the Christian population:

These left-overs from the former Young Turk Party, who should have been made to account for the lives of millions of our Christian subjects who were ruthlessly driven en masse, from their homes and massacred, have ... hitherto lived on plunder, robbery and bribery ... ${ }^{191}$

After the defeat of the Ottoman Empire in World War I, the Treaty of Sèvres recognized that the "terrorist regime" of the Young Turks had victimized their "subjects of non-Turkish race" with massacres, disappearances, forcible conversions to 
Islam, and unjust and illegal expropriations of homes and businesses. ${ }^{192}$ The treaty denied the legitimacy of Turkish claims to lands inhabited by Christians by excluding Mesopotamia, Syria, and Greece from the boundaries of the post-imperial Turkish state and purported to guarantee equal rights and religious freedom to those non-Turks and Christians remaining subjects of Turkey. ${ }^{193}$ Along with the Charter of the League of Nations and the Treaty of Versailles, the delegates to the Paris Peace Conference, most notably the president of the United States, the prime minister of Great Britain, and the premier of France, intended the Treaty of Sèvres to frame a more peaceful post-war world.

The Treaty of Sèvres, which the Ottoman government signed in 1920, required Turkey to hand over to Allied custody those of its nationals who were "responsible for the massacres" and to recognize whatever tribunal the Allied powers designated to try the perpetrators as criminals under international law. ${ }^{194}$ But by the next year the British had abandoned their prosecutions of the Young Turks and surrendered many suspects held in their custody to the new government of Atatürk, in exchange for the repatriation of British prisoners of war. ${ }^{195}$ Atatürk had promised to prosecute these leaders in Turkish courts; ${ }^{196}$ in 1923, however, his government declared a general amnesty for all those convicted of war crimes by courts-martial. ${ }^{197}$ As Atatürk threatened Mesopotamian oil reserves, Britain and France decided to conclude the Treaty of Lausanne in 1923, with its "moral horror[s]" of the Orthodox Christian expulsion from Turkey, no protections for Armenians, and a secret annex granting amnesty to Turkish war criminals. ${ }^{198}$

Despite the success of the Kemalist revolution and the concessions wrought from the oil-thirsty Entente at Lausanne, the fact remains that the Ottoman government did acknowledge the criminal character of the massacres of Christian civilians that took place during World War I. This disposes of the two principal defenses of the conduct of the Turks from the charge of genocide: that the charge that the Ottomans attempted to wipe out the Christians of the empire is merely Western propaganda, and that any alleged attempt to exterminate minority racial and religious groups did not constitute a criminal act under international law as it stood during World War I. Only one weighty legal question remains: Is there sufficient evidence of intent to eliminate a racial, ethnic, or religious group for the charge of genocide to be made in a persuasive manner?

\section{The Ottoman Plan to Exterminate the Assyrians}

Assuming that the UNCG or some other law criminalizing genocide did apply in 1915, the Turks and their defenders argue that the UNCG requires "specific intent" to destroy members of a group as such, which was lacking in the Ottoman Empire's approach to its Christian minorities, including the Armenians and Assyrians. For example, the Web site of the Turkish government states that Armenians were killed by "local Muslims," whose actions the Ottoman armies neither ordered nor participated in. ${ }^{199}$ Indeed, the Ottoman authorities ordered their subordinate officials to "protect relocated Armenians" from local Muslims. ${ }^{200}$ The British government appears to agree with this general line of argumentation, condemning "the massacres of $1915-16 \ldots$ as a tragedy of historic proportions" but not recognizing them as "genocide" because of "the absence of unequivocal evidence to show that the Ottoman administration took a specific decision to eliminate the Armenians under their control at the time."201 
Absent a governmental intention to exterminate the Christians of the empire, it would be nearly impossible to explain how the massacres, rapes, deportations, and dispossessions of the Armenian, Assyrian, and Greek Christians living in the Ottoman Empire at the time of World War I could have taken place on such a vast scale. ${ }^{202}$ How could such a remarkable degree of coordination and common purpose in slaughtering civilians, ravaging women, orphaning children, and stealing money and property have emerged without organization and direction from above? Indeed, it takes little searching to uncover abundant evidence of planning for genocide.

Interior Minister Talât, initially the most powerful member of the CUP, believed in "Turkey for the Turks," or getting rid of the ancient Christian peoples stranded in the Ottoman Empire. ${ }^{203}$ After the 1908 coup that propelled the Young Turks to positions of power in the Ottoman government, the German ambassador to Athens reported a conversation with the Turkish prime minister in which he learned that "The Turks have decided upon a war of extermination against their Christian subjects." ${ }^{204}$ In 1910, the leaders of the CUP held a party conference during which they discussed how "the complete Ottomanization of all Turkish subjects must be effected, but it was becoming clear that this could never be achieved by persuasion, and recourse must be had to force of arms." ${ }^{205}$ In 1911, a prominent Young Turk declared that the "nations that remain from the old times in our empire are akin to foreign and harmful weeds that must be uprooted."206

When the Russians advanced in the Caucasus, and the British marched north from Mesopotamia, the Ottoman "policy of [Christian] oppression broadened across the empire and increased to genocidal proportions."207 Soon after the Sultan's declaration of jihad in 1914, the Ottomans, seized with "anti-Christian chauvinism," deported into other parts of Anatolia the entire Christian population of the Gallipoli peninsula and the area around the Sea of Marmora, more than 60,000 people. ${ }^{208}$ "Christians... were cast as collective targets when Talat and Cemal threatened reprisals against them" for any Muslim war dead. ${ }^{209}$ The central government disseminated wartime propaganda of a consistently anti-Christian theme, which, surprisingly, was often written or inspired by Germans:

At the outbreak of hostilities the Germans worked with all their power to incite the Mohammedan world.... The plan was to start a holy war, as in that way it would be possible to stir into action millions of Moslems from Persia, India, Afghanistan, Baluchistan, Arabia, Turkestan, and other Mohammedan countries. With a force of from ten to fifteen million armed Mussulmans they planned to march against Russia first. Naturally, the Russians being occupied in fighting such an army, this would give the Germans better opportunities on the Western fronts...

The ablest German writers were enlisted.... It was reported that the English were destroyed and their greatest generals captured. [Proclamations reported the total defeat of the French and the Russians, and the deaths of most of the English armies.] The Moslem crusade, they said, was being carried on in Egypt, Tunis, Algeria, Afghanistan, Baluchistan, India, the Sudan. These utterly false reports constitute one of the principal reasons why the Mohammedans, in Turkey and in some other parts of the Moslem world, have been led to take sides against the cause of the Allies. ${ }^{210}$

An American missionary tasked by the US minister to Persia with providing a complete account of the massacres in that country corroborated this account, stating that

the use of the Kurdish tribes was a part of the Turkish plan of campaign, and they were urged and sent by responsible Turkish officers, military, civil and consular. It was made more dangerous to Christians by the cry of Jihad (or holy war), which was 
deliberately made use of by responsible Turkish officials.... The use of barbarous troops under little or no control against people who were non-combatants is absolutely unjustifiable and of this crime the Turks were certainly guilty. ${ }^{211}$

Similarly, James L. Barton, Foreign Secretary of the American Board of Commissioners for Foreign Missions, wrote that, "soon after Turkey entered the war on the side of the Central Powers, an effort was made to unite all the Moslem peoples under Pan-Islam and to declare a Holy War."212

By 1914, the Ottomans had built yet another apparatus of "ethnic war."213 The Teşkilat-1 Mahsusa, or Special Organization, was a force of more than 30,000 men under arms, composed of Turkish law-enforcement officers and criminal bands under the command of Ottoman army officers and CUP political leaders. ${ }^{214}$ The Special Organization eventually became "a dedicated instrument of indiscriminate mass murder." 15 As noted above, Djevdet Bey also assembled what he called "butcher battalions" for the same purpose.

In June 1915, Interior Minister Talât told the German ambassador that the Ottomans were exploiting the crisis of the war to "thoroughly clear Turkey of her internal enemies, i.e. the Christians."216 Talât told Ambassador Morgenthau that his "national policy" was that

these different blocs in the Turkish Empire... had always conspired against Turkey; because of the hostility of these native populations, Turkey had lost province after province-Greece, Serbia, Rumania, Bulgaria, Bosnia, Herzegovina, Egypt and Tripoli. In this way the Turkish Empire had dwindled almost to the vanishing point. If what was left of Turkey was to survive, added Talaat, he must get rid of these alien peoples. "Turkey for the Turks" was now Talaat's controlling idea. ${ }^{217}$

The Young Turks, Ambassador Morgenthau learned, had decided "to establish a country exclusively for Turks," so their "passion for Turkifying the nation seemed to demand logically the extermination of all Christians." 218 As a telegram from the German ambassador in Constantinople reported, Talât spoke in similar terms "without reservation" to a German diplomat, stating that the Ottoman government

is intent on taking advantage of the World War in order to [make a] clean sweep of internal enemies - the indigenous Christians-without being hindered in doing so by diplomatic intervention from other countries. Such an undertaking will serve the interest of the Germans, the Allies of Turkey, which thus in turn could be strengthened. ${ }^{219}$

The policy of a "clean sweep" to rid the Ottomans of "alien peoples" was translated into action by local commanders with close ties to the central government. In February 1915, Djevdet Bey, military governor of Van and brother-in-law of Enver Pasha himself, stated, "We have made a clean sweep [literally, "clean table"] of the Armenians and Syrians of Azerbeijan [northern Persia]; we must do the same with the Armenians of Van." 220 The previous month, he had invaded Persia and "massacred the Assyro-Chaldean populations of Persian Azerbeijan."221

By 1915, therefore, the CUP had created extermination squads and adopted "a crystallized policy of empire-wide killing and death-by-attrition." ${ }^{22}$ The Ottoman government's religious figurehead, the Sheik al-Islam, resigned from the Sultan's Cabinet after protesting "the extermination of the [Ottoman] Christian elements." 223 Ambassador Ernst Wilhelm Hohenlohe reported that the Ottoman "government is resolved ... to eliminate the indigenous Christians." 224 A telegram from Mosul to the German consul in Constantinople related news from the leaders of the Assyrian and Chaldean churches that "the Muslims in the district of Amadia planned a general Christian massacre and had already begun with it; the governor admits the fact and 
the policy seems to be, if not quite to stir it up, to restrain it not very energetically." ${ }^{225}$ Lepsius added that "all Christians have suffered the same fate without differentiation as to race or denomination." 226

Along with the Armenians, the Assyrians were targeted as a group of non-Turkish Christians in a way that "can only be explained by the CUP's increasingly radical ideology of ethnic [and religious] exclusivity." 227 As Peter Balakian has demonstrated, by 1915 one million people had died in "the extermination of innocent civilians in Turkey (the Armenians, but also Syrian and Assyrian Christians and large portions of the Greek population....)."228 Such a speedy and well-organized annihilation of the indigenous Christians of the Ottoman Empire could scarcely have taken place other than as a result of intentional planning and execution.

In any event, the intention on the part of Ottoman officials to exterminate their Armenian and Assyrian subjects need not be proven exclusively by means of confessions or admissions. ${ }^{229}$ As the International Criminal Tribunals for the Former Yugoslavia and for Rwanda have made clear, "genocidal intent [may] be inferred from the physical acts and specifically 'their massive and/or systematic nature of their atrocity." 230 The Tribunals have recognized that even "in the absence of a confession from the accused, his intent can be inferred from...the perpetration of other culpable acts systematically directed against that same group, whether these acts were committed by the same offender or by others."231

Thus, the element of specific intent to commit genocide may be based upon the testimony of the victims and direct physical evidence, such that a confession or admission of genocidal intent is not necessary. Evidence of many "culpable acts [that] were perpetrated systematically against the same group," including those committed by "other perpetrators," may suffice as evidence of intent. ${ }^{232}$ Mass rape targeting Assyrian women and children, and the consequent interference with births within and reproductive survival of the group, also manifested a genocidal intent. ${ }^{233}$ The deportation of the Assyrians, and the consequent deprivation of their established means of sustenance, shelter, and dignified living, was a genocidal policy. ${ }^{234}$ The dispossession of the Assyrians from their homes and agricultural lands, moreover, tended to deprive them of the conditions necessary for bare life, let alone a civilized or dignified life, and therefore served to destroy the group as such. ${ }^{235}$ In sum, the "inhuman treatment, torture, rape, sexual abuse and deportation" of the Assyrians, along with the "deliberate destruction" of their houses and places of worship, establishes an intention by Ottoman officials to exterminate them as a group. ${ }^{236}$

Some may argue that it matters little to the victims, or to us, whether the Ottomans committed genocide, crimes against humanity, war crimes, extermination, "ethnic cleansing," persecution, "atrocities," or simple murder. It is not clear, however, that each of these other crimes outlaws conduct short of murder that causes deaths or prevents births within an ethnic or religious group with the intent of destroying all or part of the group, such as "causing serious ... mental harm to members of the group," "deliberately inflicting on the group conditions of life calculated to bring about its physical destruction in whole or in part," or "imposing measures intended to prevent births within the group." ${ }^{237}$ Moreover, the concept and legal category of genocide must be invoked for the sake of applying a consistent standard of international law and in order to grasp the full implications and seriousness of what happened to the Assyrians from 1914 to 1918, not to mention 1844 to 1846, 1896 to 1904, and 1918 to 1933 . As Raphael Lemkin wrote in coining the term, "genocide" was intended to cover just such a situation, in which "a co-ordinated plan of different actions aiming at the 
destruction of essential foundations of the life of national groups" is executed. ${ }^{238}$ Genocide is a particularly grave violation of international law precisely because the world loses "future contributions" that would be "based upon [the destroyed group's] genuine traditions, genuine culture, and...well-developed national psychology."239 The widespread devastation of Assyrian communities, cultural property, and young people with the potential to enlighten and fascinate the entire world was just such an appalling loss to the region and to humanity.

\section{The Struggle for Recognition of the Assyrian Genocide}

The Armenian state and diaspora population have secured widespread international recognition of the Armenian Genocide by Western governments and international institutions otherwise on good terms with Turkey. US presidents Gerald Ford, Jimmy Carter, Ronald Reagan, and George W. Bush have each acknowledged the Armenian Genocide. ${ }^{240}$ The House of Representatives of the United States has passed several resolutions recognizing the genocide of the Armenians, ${ }^{241}$ and at least twenty-three US states have commemorated or officially recognized the Armenian genocide. ${ }^{242}$

The United Nations, the European Parliament, and the Catholic Church have acknowledged the Armenian Genocide as a historical fact. ${ }^{243}$ France, which has the largest Armenian diaspora population outside the United States, has acknowledged the Armenian genocide through its parliament. ${ }^{244}$ Its foreign minister has gone so far as to state that Turkey must "recognize this tragedy" before applying for membership in the European Union. ${ }^{245}$ Along with France, the parliaments of Russia, Canada, Argentina, Poland, Greece, Switzerland, and Belgium have passed resolutions on the genocide. $^{246}$

By comparison, no US president, congressional body, or US state has recognized the Assyrian genocide; nor has the United Nations, any European state, or any prominent scholar of the Armenian genocide, so far as the author is aware. ${ }^{247}$ Part of their reluctance may be due to the more extensive historical documentation of Ottoman confessions and admissions of anti-Armenian extermination policies. ${ }^{248}$ Although a great deal of the evidence of genocidal intent deals with Christians more broadly, much of it is specific to the elimination of the Armenian people. ${ }^{249}$

A requirement of a confession or other direct evidence of genocidal intent is not supported by the law, however. The evidence of Ottoman-directed massacres, rapes, deportations, and property expropriations is more than sufficient to establish a pattern of systematic and discriminatory attacks on Assyrians from which a genocidal intent may be inferred. ${ }^{250}$ As the tribunal hearing the case of Slobodan Milosevic held, while direct evidence of genocide is theoretically possible, genocidal intent will more typically be inferred from systematic attacks on or targeting of a group, atrocities on a large scale, or repetitive "destructive and discriminatory acts." 251

Aside from questions about the sufficiency of the documentary evidence, the Assyrians may have struggled unsuccessfully to achieve recognition of their experience of genocide because fewer absolute numbers of them than of the Armenians survived the Ottoman genocide of Christians. As a smaller population, the Assyrians suffered fewer total deaths than the Armenians, failed to win statehood after World War I, as the Armenians did, and did not mount similarly ambitious and effective lobbying efforts. The worldwide Armenian population stands at an estimated nine to ten million people, substantially larger than the estimated four million Assyrians living around the world. ${ }^{252}$ The three million Armenians living in and controlling the state of Armenia outnumber and can outmaneuver the 600,000 to one million Assyrians 
living in but largely excluded from political power in their traditional Mesopotamian homeland. ${ }^{253}$ The estimated one million Armenians living in the United States, concentrated in southern California, also exercise dramatically more political clout than the 350,000 marginalized Assyrians dispersed across central California, Michigan, and Illinois. ${ }^{254}$

\section{Preventing Genocide and Ethnic Cleansing against the Assyrians in Present-Day Iraq}

Present-day Iraq is a state at high risk of genocide, according to a model for early warning of genocidal violence developed for the US government. ${ }^{255}$ Many of the warning signs of previous genocides, such as those in Turkey, German-occupied Europe, Yugoslavia, and Rwanda, are present in Iraq, including demonization of minority groups, unfair scapegoating of minorities for the problems of the majority population, and refugee flight. ${ }^{256}$

This would be the most recent such genocidal assault against the Assyrians, after the Ottoman genocide of Christians, the massacre of up to 3,000 Assyrians by Iraqi armed forces and Kurdish militia in 1933, and the disappearance of 1,000 Assyrians during the Ba'athist "Arabization" and "Anfal" campaigns of the 1970s and 1980s. ${ }^{257}$ "Military forces destroyed many Assyrian churches during the Anfal Campaign, and reportedly tortured and executed many Assyrians." 258 Assyrians suffered from chemical weapons attacks in Halabja and elsewhere. ${ }^{259}$ Widespread discrimination against Iraqi Christians and Kurds in the name of "Arabization" continued into 2001, especially in the area around Kirkuk, and drove 100,000 people from their homes and villages. ${ }^{260}$ Between 1963 and 1987, the Iraqi government destroyed about 200 majority Assyrian villages in the provinces of Nineveh, Dohuk, and Arbil. ${ }^{261}$ Many of these villages housed 100 to 200 families each. ${ }^{262}$ The Iraqi government razed almost twenty-five churches, monasteries, and religious-run orphanages during this period. $^{263}$ Assyrian political activists have also claimed that up to 40,000 Assyrians were conscripted and killed, wounded, taken prisoner, or went missing during the Iran-Iraq War. ${ }^{264}$

Hundreds of thousands of Assyrians fled Iraq during Saddam Hussein's rule from 1979 to 2003. Up to half of the Assyrian population has fled Iraq since $1991 .^{265}$ As British political journalist Alastair Bruton has pointed out in the New York Times, the Kurdish regions of Iraq and Turkey were subject to "ethnic cleansing" for over a decade, as "the Kurds have driven tens of thousands of Assyrians and Chaldeans into exile, and yet Western commentators persist in their naive belief that the Kurds are the only oppressed people in the region." ${ }^{266}$ Millions of Assyrians and Chaldeans now live in exile, including about 400,000 in the United States and hundreds of thousands more in the European Union, Russia, Canada, Australia, New Zealand, and other nations offering asylum to victims of religious persecution. ${ }^{267}$

The vice-chair of the US Commission on International Religious Freedom has warned of a new "ethnic-cleansing campaign" against Assyrians, with violence against Assyrians intensifying since the 2003 war to depose Saddam Hussein. ${ }^{268}$ Humanrights reports issued in the years immediately preceding the 2003 war by the United Nations and the governments of the United States and the United Kingdom cited isolated killings and widespread ethnic and religious discrimination against Assyrians. ${ }^{269}$ By comparison, similar reports issued since the 2003 war acknowledge "systematic attacks" against Assyrians. ${ }^{270}$ Among other incidents, "more than 100 Christians had been murdered after the U.S.-led war," 271 including eleven people 
killed during bombings of Christian churches and seven people riding on a bus who were massacred in one day in October 2004; ${ }^{272}$ three Christians were killed in Basra for selling alcohol, and Christian women there have been assaulted for not wearing veils, prompting most Christian families formerly living in Basra to flee fundamentalism in Iraq; ${ }^{273}$ and a campaign of kidnappings has terrorized Iraqi Christians at a rate of two or three disappeared per week in Baghdad alone. ${ }^{274}$

Half of those Christians who remained in Iraq after the fall of Saddam Hussein's regime have since been driven from the country by horrific violence and medieval fundamentalism. ${ }^{275}$ About 300,000 Christians fled their homes in Iraq between March 2003 war and August 2005 alone, many languishing as refugees in Syria, Lebanon, Jordan, Turkey, and Iran. ${ }^{276}$ About 80,000 have emigrated out of Iraq altogether, while the remainder is presumably displaced internally. ${ }^{277}$ More than 15,000 Assyrians left Iraq in just three months after a coordinated series of church bombings in August 2004. ${ }^{278}$

Preventing the dispossession and exile of the Christians of Iraq will require acknowledging their historical persecution and taking concrete steps to block its recurrence. The failure to acknowledge and punish the perpetrators of the Ottoman genocide has probably emboldened other despots in the region, notably the rulers of Iraq, Turkey, Iran, Saudi Arabia, and Sudan, to massacre and persecute their Christian and non-Arab minorities. After all, once American and British diplomats admitted abandoning their Christian allies among the Armenians, Assyrians, and Greeks to the massacres of the Turks and Kurds, ${ }^{279}$ why should future Turkish, Arab, or Kurdish authorities fear international laws against oppressing minorities?

The example of the German Holocaust of Jews, Slavs, Roma, leftists, homosexuals, and other minorities also underlines the importance of punishing one genocide in order to deter others. Near the end of World War II in Europe, an American official with firsthand knowledge of the persecution of the Jews and other minorities in Europe reported that the "failure to punish criminals of World War I may well have removed a deterrent to the commission of brutalities against civilian populations in this war, including the mass murder of the Jews."280 Nazi officials at the highest levels perceived Allied tolerance of genocidal policies toward racial and religious minorities in World War I as a green light to engage in the same practices in World War II. Adolf Hitler, noting that history often views a mass-murdering conqueror such as Genghis Khan as "the great founder of States," stated that

in the East I have put my death-head formations in place with the command relentlessly and without compassion to send into death many women and children of Polish origin and language.... Who after all is today speaking about the destruction of the Armenians? ${ }^{281}$

Likewise, Joseph Goebbels recorded in his diary in 1942 his belief that "both the English and the Americans are happy that we are exterminating the Jewish riff-raff." 282

Conversely, the international norm against genocide has been shown to be effective under certain circumstances, even against a high Nazi official in the midst of an unprecedented world war. At the close of World War II in Europe, key Holocaust architect Heinrich Himmler "ordered an end to the death marches of the Jews, fearing that continued murders would embarrass him in talks with America." ${ }^{283}$ Other populations have been spared the continuation of genocidal campaigns started against them; examples of this phenomenon include the residents of independent Armenia, Israel, East Pakistan (Bangladesh), Bosnia, and East Timor. ${ }^{284}$ 
It is beyond the scope of this paper, but a fertile ground for further research, to ask whether the Assyrians of Iraq, who have been dispersed into non-viable minority communities since the Ottoman genocide, would be better served by liberalizing refugee and asylum laws to facilitate their resettlement in the West, or whether, in addition to or in lieu of such liberalization, they require the establishment of a safe haven from religious persecution inside Iraq. ${ }^{285}$ The global asylum system is not currently adequate to deal with the flood of Assyrian refugees out of Iraq, who often end up dying en route to the West, or being imprisoned for illegal entry. ${ }^{286} \mathrm{~A}$ safe haven inside Iraq for Assyrians unable to resettle in the West would find ample support in Assyrians' right to self-determination under international law, which long predated Iraq's new "permanent" constitution. ${ }^{287}$ Without international support for such an Assyrian safe haven, tens of thousands of Christian refugees may continue to flee Iraq each year.

Whether the solution to their plight lies in international immigration or in local autonomy, the Assyrians desperately need financial support for resettling their refugees and replacing the homes, villages, and personal and cultural property destroyed over the past century by the Turks, Arabs, and Kurds. Genocide and ethnic cleansing give rise to legally enforceable claims for reparation and restoration of property and the value of lives lost. ${ }^{288}$ Perhaps because their genocide has rarely been recognized, the Assyrians driven from their homes over the past century have received relatively little by way of compensation or assistance with rebuilding. Although the United States has spent close to $\$ 3$ billion on the reconstruction of northern Iraq, it seems that less than $\$ 35$ million has gone to Assyrian towns and villages. ${ }^{289}$ Local Iraqi leaders have systematically excluded Assyrians from the distribution of reconstruction assistance. ${ }^{290}$ By comparison, the United Nations has forced Iraqis to pay over $\$ 19.2$ billion in compensation to those harmed by the 1991 Iraqi invasion of Kuwait, which caused far fewer deaths than even the Anfal campaign of the 1980s, let alone the Ottoman genocide of the Armenians and Assyrians. ${ }^{291}$

To make an Assyrian safe haven a viable option for Christian refugees, a just proportion of the Iraqi reconstruction spending authorized by the United States and the international community would need to be specifically earmarked to security, resettlement, and rebuilding of at least those Assyrian villages destroyed in the ethnic cleansing campaigns of the Saddam Hussein regime. ${ }^{292}$ Independent Assyrian administrators could be charged with spending these funds, to prevent their continuing to be diverted to other Iraqis. With this international support, Assyrian victims of religious persecution in Iraq and neighboring states such as Syria, Jordan, Turkey, and Iran who are denied entry into Europe, North America, and so on could rebuild their lives in a safe haven.

\section{Conclusion: Recognizing a Legacy}

Many analogies may be drawn between the experience of the Assyrians during World War I and other acknowledged genocides, including not only the Armenian Genocide but also the Holocaust of Jews, Slavs, Roma, leftists, homosexuals, and other minorities under Nazi occupation during World War II. ${ }^{293}$ The Assyrians and other Ottoman Christians, like the Jews, had suffered from centuries of discrimination and official segregation; were charged with being agents of foreign powers and scapegoated for military defeats and looming threats in a rhetoric of ethnic elimination; and were physically and culturally exterminated in large numbers by means of massacres, 
rapes, expulsions, and attacks on homes and religious institutions carried out by genocidal state apparatuses and local irregular forces. ${ }^{294}$ Just as the Holocaust reached its full expression only after the invasion of Poland and the world war with Britain and the Soviet Union, so the genocide of Christian populations reached its most intense phase only after the outbreak of war with Britain and Russia and the Ottoman invasion of Persia. ${ }^{295}$

Although the primary blame for the genocide of the Assyrians lies with the Ottoman officials who distributed the proclamations of jihad, massacred civilians and outraged women, and instigated their Kurdish and Persian allies to do the same, the West bears a heavy responsibility. Disgraceful rivalries among the Great Powers facilitated Turkish violations against the Armenians, Assyrians, Greeks, and other Christian and non-Christian minorities, both during the waning years of the Ottoman Empire and in the independent Kemalist Turkey that followed it. Britain's alliance with Turkey during the Crimean War repelled a Russian attempt to liberate the Ottoman Christians from the subjugation and periodic slaughter to which they had been condemned by Turkish rule. ${ }^{296}$ After the Hamidiye massacres and during World War I, the Germans acted as the Ottomans' Christian ally, actually encouraging the Sultan to declare a jihad against the Christian allies of the British, without regard for the consequences. ${ }^{297}$

This dolorous history continued throughout the twentieth century, with Western powers such as the United States, Great Britain, and France financing and aiding oppressive Turkish and Arab rule over the Christian remnant in Asia and even in Europe, in the case of Cyprus. ${ }^{298}$ Western powers largely ignored abuses against Christians in Turkey and Iraq, continuing to extend military aid and diplomatic support. ${ }^{299}$ The United States remains the principal supplier of Turkish military equipment, which is used to blockade tiny landlocked Armenia and threaten military intervention against it for protecting the ethnic Armenians of Azerbaijan. ${ }^{300}$ The Soviet Union, for its part, was the principal source of Iraqi weaponry in the late 1980s, the period of the Anfal and Arabization campaigns. ${ }^{301}$

Unfortunately, the West has rejected the idea of solidarity with the Christians of the Middle East, prioritizing diplomacy based on oil interests and the Arab-Israeli conflict. ${ }^{302}$ Thus, the United States, Britain, and France have largely ignored the persecutions of the Christians of Iraq, Lebanon, Egypt, and Sudan, while rushing to save the oil-rich Muslim states of Saudi Arabia and Kuwait, as well as besieged minority Kurds, Bosnians, and Kosovars. ${ }^{303}$ To this day, American troops in Iraq reportedly do not always intervene against the persecution of Christians, perhaps not wanting to be seen as "siding with the Christians" and thus provoke retaliation. 304

As the West, and the world in general, becomes more familiar with the history of the Armenians, Assyrians, and other victims of genocide, the prospects for adequate reparation for such events, and their future prevention, may improve. This essay has demonstrated that the Ottoman genocide of the Assyrians took place, that it followed centuries of violent persecution of the Assyrians by Muslim rulers, that it intensified after the outbreak of international war against Western Christian nations, and that it was implemented by Ottoman troops and their local militia allies via massacre, systematic rape, deportation, the destruction of homes and villages, and cultural annihilation. These findings may contribute to identifying and preventing other cases of genocide against Christian minorities living in majority Muslim states, such as Sudan and Nigeria, in which religiously motivated massacres are becoming more common. ${ }^{305}$ 


\section{Notes}

1. See, e.g., C.J. Chivers, "Uprooted Iraqis See War as Path to Lost Homes," New York Times, 5 December 2002, A1; David Rohde, "View from Ancient Monastery as Yet Another War Intrudes," New York Times, 10 April 2003, B6; Craig S. Smith, "Teacher, a Survivor, Fondly Recalls Life in Hussein's Iraq," New York Times, 19 April 2003, B2; Sabrina Tavernise, "In a Muslim City in Iraq, a Christian Group Enjoys Its Lively Quarter," New York Times, 23 May 2003, A2; Paul Marshall, "Elsewhere in Iraq," Wall Street Journal, 22 August 2003, http://www.opinionjournal.com/taste/?id=110003917 (accessed 11 October 2006); Leela Jacinto, “Is Jesus' Language at Death's Door? Iraqi Assyrians Speak the Language Jesus Spoke-But For How Long?” ABC News.com, 6 November 2003, http://abcnews.go.com/International/story?id=79814\&page $=1$ (accessed 11 October 2006); Katherine Zoepf, "Many Christians Flee Iraq, with Syria the Haven of Choice," New York Times, 5 August 2004, A11; Katherine Zoepf, "Turkey Allows a First New Year for a Tiny Minority," New York Times, 4 April 2005. Prior to the 2003 war, the vast majority of articles in the American press concerned ancient Assyrian civilization or artifacts, not modern Assyrian life. Long before the latest war, however, the Catholic wire service Zenit and the Catholic News Service provided consistently high-quality reporting on the situation of Iraqi Christians, especially Chaldean Catholics. See, e.g., "Patriarch of Iraq Makes a Plea for Peace to The American People," Zenit, 18 February 1998, http:// www.zenit.org/english/archive/9802/zw980218.htm\#a1 (accessed 11 October 2006); John Thavis, "Modern-Day Exodus: Flight of Catholics from Iraq Troubles Vatican," National Catholic Reporter/Catholic News Service, 28 February 2003, http://www.findarticles.com/ p/articles/mi_m1141/is_17_39/ai_98541113 (accessed 11 October 2006).

2. In this essay, I will refer to the Assyrians, Nestorians, Chaldeans, and Syrian/Syriac Christians collectively as Assyrians. Although this usage is controversial among Chaldean Catholics in particular, it accurately conveys the fact that "Nestorian," "Syrian/Syriac," and "Chaldean" are religious denominations whose members are descended principally from the inhabitants of ancient Assyria, who converted to Christianity starting in the first or second century CE. George M. Lamsa and William Chauncey Emhardt, The Oldest Christian People (New York: Macmillan, 1926), 20-22, 49, 78-79, 92-95; Jackie Lyden, "Despite Turmoil, Christians Place Faith in New Iraq," All Things Considered, NPR, 13 August 2005, http://www.npr.org/templates/story/story.php?storyId=4799390 (accessed 17 February 2006). Assyrians, Chaldeans, and Syriacs also shared an ancestry-group designation in the 2000 US Census, even though Chaldeans are increasingly describing themselves as part of a distinct ethnic group from the Assyrians. Nicholas Kulish, "Chaldeans, Assyrians Vexed by Count," Wall Street Journal, 18 March 2001, C8; "U.S. Judge Rejects Assyrian Protest," Risk Monitor Briefing, 22 October 2000.

3. Sarah C. Melville, "Neo-Assyrian Royal Women and Male Identity: Status as a Social Tool," Journal of the American Oriental Society 124, 1 (2004): 37-57; Pauline Albenda, "Western Asiatic Women in the Iron Age: Their Image Revealed," The Biblical Archaeologist 46 (1983): 82-88; Khaldun S. Husry, "The Assyrian Affair of 1933 (I)," International Journal of Middle East Studies 5 (1974), 164-76; Gibson McGuire, "Studies in the Ancient History of Northern Iraq (Review)," Journal of Near Eastern Studies 31 (1972): 42-46.

4. For its 300 years as the "first real world empire," Assyria's "service in forwarding the progress of the world was important and indispensable"-for example, in developing "political organization on a large scale" and distributing technology, trade, civilization, and culture throughout Western Asia and Greece. George S. Godspeed, "A Sketch of Assyrian History," The Biblical World 9 (1897): 401-14, 414. Assyrian, also known as Akkadian, served as the dominant language of the Middle East for more than 2,500 years; using it, law, science, religion, and poetry were developed. Wolfgang Saxon, "Erica Reiner Is Dead at 81: Renowned Assyrian Scholar," New York Times, 22 January 2006, 1-32.

5. Wilhelm Baum and Dietmar W. Winkler, The Church of the East: A Concise History (London: RoutledgeCurzon, 2003), 11-15. 
6. Jonathan Berkey, The Formation of Islam: Religion and Society in the Near East, 600-1800 (Cambridge: Cambridge University Press, 2003), 24.

7. Robin E. Waterfield, Christians in Persia (London: Harper \& Row, 1973), 23; Paul Gavrilyuk, "Theopatheia: Nestorius's Main Charge against Cyril of Alexandria," Scottish Journal of Theology 56 (2003): 190-207; Jonathan Eric Lewis, "Iraqi Assyrians: Barometer of Pluralism," Middle East Quarterly 10 (2003): 49-58; Carl E. Braaten, "Modern Interpretations of Nestorius," Church History 32 (1963): 251-67; "Nestorius and Nestorianism," The Catholic Encyclopedia, vol. 10 (New York: Robert Appleton, 1911), http://www.newadvent.org/cathen/10755a.htm (accessed February 17, 2006).

8. Edward Gibbon, The History of the Decline and Fall of the Roman Empire (London, 1781; reprint, New York: Fred de Fau, 1906), vol. 8, ch. 47, s. IV, http://oll.libertyfund.org/ Home3/HTML.php?recordID=0214.08 (accessed 12 October 2006); John M.L. Young, By Foot to China: Mission of the Church of the East, to 1400 (Lookout Mountain, GA: Grey Pilgrim Publications, 1991), ch. 3, http://www.aina.org/books/bftc/bftc.htm (accessed 12 October 2006); Stephen Andrew Missick, "Mar Thoma: The Apostolic Foundation of the Assyrian Church and the Christians of St. Thomas in India," Journal of Assyrian Academic Studies 24 (2000): 33-61, http://jaas.org/edocs/v14n2/missick.pdf (accessed 12 October 2006).

9. Lewis, "Iraqi Assyrians," 50.

10. The Greek historian Herodotus, writing almost 200 years later, referred to all of Mesopotamia as Assyria, even though the major Assyrian cities had been destroyed in 612 BCE. See John Joseph, Muslim-Christian Relations and Inter-Christian Rivalries in the Middle East: The Case of the Jacobites in an Age of Transition (Albany: State University of New York Press, 1983), 150; Herodotus, The Histories, trans. Harry Carter (New York: Heritage Press, 1958), 431. Another 200 years later, under Parthian rule, many Assyrian cities were "resurrected" and, with the aid of other, mostly Semitic peoples, the former capital of Assur was rebuilt to the size it had been during the Assyrian empire. See George Roux, Ancient Iraq, 3rd ed. (London: Penguin, 1992), 419.

11. See Fred Aprim, Assyrians: The Continuous Saga (Philadelphia: Xlibris, 2004); "Parthia," in The Cambridge Ancient History: The Roman Republic, 2nd ed., vol. 3, pt. 2 (Cambridge: Cambridge University Press, 1991), 597-98; Patricia Crone and Michael Cook, Hagarism: The Making of the Islamic World (Cambridge: Cambridge University Press, 1980), 55-60; "Ashurbanipal and the Fall of Assyria," in The Cambridge Ancient History: The Assyrian Empire, vol. 3 (Cambridge: Cambridge University Press, 1954), 130-31; A.T. Olmstead, History of the Persian Empire (Chicago: University of Chicago Press, 1948), 168; Albert Hourani, Minorities in the Arab World (London: Oxford University Press, 1947), 99; Aubrey Vine, The Nestorian Churches (London: Independent Press, 1937); Hurmuzd Rassam, Assur and the Land of Nimrud (Cincinnati, OH: Curts \& Jennings, 1897), 173-74; George Percy Badger, The Nestorians and Their Rituals (London: Darf Publishers Ltd., 1987) (1852); George Percy Badger, The Christians of Assyria Commonly Called Nestorians (London: W.H. Bartlett, 1869); Gibbon, Decline and Fall, vol. 8, ch. 47, http:// oll.libertyfund.org/Home3/HTML.php?recordID=0214.08 (accessed 12 October 2006); Flavius Josephus, The Antiquities of the Jews, trans. William Whiston (1737), bk. 13, ch. 6, http://www.ccel.org/j/josephus/works/ant-13.htm (accessed 12 October 2006); Simo Parpola, "National and Ethnic Identity in the Neo-Assyrian Empire and Assyrian Identity in the Post-Empire Times," Journal of Assyrian Academic Studies 18, 2 (2004): 16-17; Odisho Malko Gewargis, "We Are Assyrians," Journal of Assyrian Academic Studies 16, 1 (2002): 77-95, http://www.jaas.org/edocs/v16n1/WeAreAssyrians.pdf (accessed 12 October 2006); Simo Parpola, "Assyrians after Assyria," Journal of Assyrian Academic Studies 12, 2 (2000): 1-13; R.N. Frye, "A Postscript to My Article [Assyria and Syria: Synonyms]," Journal of Assyrian Academic Studies 11 (1997): 35-36; M.A. Dandamayev, "Assyrian Traditions during Achemenid Times," in Helsinki Assyria 1995: Proceedings of the 10th Anniversary Symposium of the Neo-Assyrian Text Corpus Project, ed. Simo Parpola and R.M. Whiting, 41-48 (Warsaw, IN: Eisenbrauns, 1997); R.N. Frye, "Assyria and 
Syria: Synonyms," Journal of the Near East Society 51 (1992): 281-85; E.W. MacDowell, "The Ancient Nestorian Church and Its Present Influence in Kurdistan," Journal of Race Development 2 (1911): 67-88, 77.

12. Michael G. Morony, Iraq after the Muslim Conquest (Princeton, NJ: Princeton University Press, 1984), 336, 345; George E. Kirk, "A Short History of the Middle East," in The Middle East Yesterday and Today, ed. David W. Miller and Clark D. Moore, 105-11 (New York: Bantam Pathfinder, 1970), 106; De Lacy O'Leary, How Greek Science Passed to the Arabs (London: Routledge \& Kegan Paul, 1949; reprint, London: Routledge \& Kegan Paul, 2001), ch. 1, http://www.aina.org/books/hgsptta.htm (accessed 12 October 2006).

13. The language of the modern Assyrians is "extraordinarily similar" to the Aramaic language of the Assyrian empire. J.G. Browne, "The Assyrians," Journal of the Royal Society of Arts 85 (1937): 170-82, 172. See also Michael D. Coogan, ed., The Oxford History of the Biblical World (New York: Oxford University Press, 2001), 279; J.F. Coakley, The Church of the East and the Church of England (Oxford: Clarendon Press, 1992), 366; Jacinto, "At Death's Door?"

14. Coakley, The Church of the East, 65, 89, 99, 149, 366-67, 382, 411. The Church of England established a mission to the Assyrians by the 1870s or 1880s, long before an independent Assyrian nation became an international legal and political issue after World War I.

15. Specifically, the idea that the modern Assyrians are descended from the ancient Assyrians finds some support in a genetic study conducted by researchers from the University of Newcastle upon Tyne, England, and the University of Tehran, Iran, which found that the Assyrians of Urmia in particular, and of Tehran to a lesser extent, were genetically similar to one another and supported the oral tradition of Assyrians being a "closed" population with little "intermixture" with the Muslim Iranian population. M.T. Akbari, Sunder S. Papiha, D.F. Roberts, and Daryoush D. Farhud, "Genetic Differentiation among Iranian Christian Communities," American Journal of Human Genetics 38 (1986): 84-98. This result is somewhat analogous to the results of a study finding substantial genetic continuity among Armenians, Jews, and Kurds despite centuries of Arab rule. See Almut Nebel, Dvora Filon, Bernd Brinkmann, Partha P. Majumder, Marina Faerman, and Ariella Oppenheim, "The Y Chromosome Pool of Jews as Part of the Genetic Landscape of the Middle East," American Journal of Human Genetics 69 (2001): 1095-1112, www.pubmedcentral.nih.gov/articlerender.fcgi?artid=1274378 (accessed 12 October 2006).

16. Christopher Johnston, "The Fall of Nineveh," Journal of the American Oriental Society 22 (1901): 20-22.

17. Waterfield, Christians in Persia, 33; Gibbon, Decline and Fall, vol. 9, ch. 51, s. V, http:// oll.libertyfund.org/Home3/HTML.php?recordID=0214.09 (accessed 12 October 2006).

18. Abraham Yohannan, The Death of a Nation, Or, The Ever Persecuted Nestorians or Assyrian Christians (New York: G.P. Putnam's Sons, 1916), 95-98. The Caliph Omar I, who ruled for a decade starting in the year $634 \mathrm{CE}$, decreed that all property in the Arabs' empire would henceforth be owned by the Muslim community. See Alfred Guillaume, "Islam," in The Middle East Yesterday and Today, ed. David W. Miller and Clark D. Moore, 100-103 (New York: Bantam Pathfinder, 1970), 101. Onerous taxes levied on non-Muslims led many Christians to convert to Islam and to become Arabs by the fiction of adoption by an Arab tribe. Ibid. "In the ten years of the administration of Omar, the [Arabs] ... destroyed four thousand churches or temples of the unbelievers." Gibbon, Decline and Fall, vol. 9, ch. 51, http://oll.libertyfund.org/Home3/ HTML.php?recordID=0214.09. The "confiscation of whole or part of [Christian] property that almost invariably took place" prompted either "wholesale secessions to Muhammedanism, or emigration to other lands." John Stewart, The Missionary Enterprise: The Story of a Church on Fire (London: T\&T Allen, 1928), 215. The Caliph Mutawakkil ordered churches built after the Muslim conquest to be torn down, and the houses of rich Christians converted into mosques. Ibid., 218. 
19. Helen Chapin Metz "The Abbasid Caliphate, 750-1258," in Iraq: A Country Study, 4th ed. (Washington, DC: Federal Research Division, Library of Congress, 1990), ch. 1, http:// countrystudies.us/iraq/16.htm (accessed 16 October 2006).

20. Ibid.

21. Yohannan, Death of a Nation, 104-10; Gabriel Oussani, "The Modern Chaldeans and Nestorians, and the Study of Syriac among Them," Journal of the American Oriental Society 22 (1901): 79-96, 82. "Under Timur Lane (1396-1405) the Nestorian churches in Asia and China were wiped out, and Nestorians ... survived chiefly in the region of the Hakkiari Mountain [sic] in Kurdistan, in great poverty and ignorance, almost unknown to the world until the nineteenth century." Hugh Wybrew, "Eastern Christianity since 451," in The World's Religions, ed. Stewart R. Sutherland, 167-92 (London: Routledge 1988), 182. "Most of the [Nestorian] monasteries were forcibly emptied or destroyed during the Mongol occupations...." Edward G. Mathews, "Nestorian Monasticism," in Encyclopedia of Monasticism, ed. William M. Johnston, 931-34 (Chicago: Fitzroy Dearborn, 2000), 933.2. "Timur was a fanatical Moslem, and his persecutions and massacres were particularly directed against the Mosul district where Christianity had survived to a much greater extent than round Baghdad." Lt. Col. Ronald Sempill Stafford, The Tragedy of the Assyrians (1935; reprint, London: Kegan Paul International, 2004), 21 n. 2.

22. Metz, Iraq; Charles Tripp, A History of Iraq (Cambridge: Cambridge University Press, 2002), 8-9, 13-14; Stanford J. Shaw, History of the Ottoman Empire and Modern Turkey, vol. 1 (Cambridge: Cambridge University Press, 2000), 95-96.

23. See John Joseph, The Modern Assyrians of the Middle East: Encounters with Western Christian Missions, Archaeologists, and Colonial Powers (Leiden: Brill, 2000), 73, 83; Waterfield, Christians in Persia; Coakley, Church of the East, 40; Yohannan, Death of a Nation, 111-12; Stafford, Tragedy of the Assyrians, ch. 1; William Ainger Wigram, The Assyrians and Their Neighbours (London: G. Bell \& Sons, 1929), ch. 8, http:// www.aina.org/books/aatn.htm (accessed 12 October 2006).

24. Yohannan, Death of a Nation, 144, 149-50.

25. Ibid.

26. Slave markets in and around Istanbul, and the kidnapping of Armenians and other Christians for slavery, survived well into the mid- to late nineteenth century. James J. Reid, Total War, the Annihilation Ethic, and the Armenian Genocide, 1870-1918 (New York: Palgrave Macmillan, 1992), 43; Y. Hakan Erdem, Slavery in the Ottoman Empire and Its Demise, 1800-1909 (New York: St. Martin's, 1996); Ehud R. Toledano, Slavery and Abolition in the Ottoman Middle East (Seattle: University of Washington Press, 1996); Ehud R. Toledano, The Ottoman Slave Trade and Its Suppression, 1840-1890 (Princeton, NJ: Princeton University Press, 1983). In the Ottoman Empire, "enslaving Christians had been elevated to something approaching state policy" from the sixteenth century, if not earlier. Robert C. Davis, Christian Slaves, Muslim Masters: White Slavery in the Mediterranean, the Barbary Coast and Italy, 1500-1800 (New York: Palgrave Macmillan, 2003), 28.

27. Michael M. Gunter, "The Kurdish Question in Perspective," World Affairs 166 (2004): 197-205, http://www.findarticles.com/p/articles/mi_m2393/is_4_166/ai_114631687/pg_2 (accessed 12 October 2006).

28. Peter Balakian, The Burning Tigris: The Armenian Genocide and America's Response (New York: HarperCollins, 2004), 43-44, 50-51, 123. For its part, the Sudanese government has sponsored a majority Arab militia called the Janjaweed to attack members of indigenous African tribes in Darfur associated with the Sudan Liberation Army; the militia engaged in the widespread killing and raping of civilians, looting and burning hundreds of villages and driving a million people from their homes. Nsongurua J. Udombana, "When Neutrality Is a Sin: The Darfur Crisis and the Crisis of Humanitarian Intervention in Sudan," Human Rights Quarterly 27 (2005): 1149-99; Human Rights Watch, Darfur Destroyed: Ethnic Cleansing by Government and Militia Forces in Western 
Sudan (New York: Human Rights Watch, 2004), http://hrw.org/reports/2004/sudan0504 (accessed 12 October 2006); Amnesty International, "Sudan: Arming the Perpetrators of Grave Abuses in Darfur" (AI Document AFR 54/139/2004, 16 November 2004), http:// web.amnesty.org/library/index/engafr541392004 (accessed 12 October 2006); US Department of State, Documenting Atrocities in Darfur (State Publication No. 11182, 21 September 2004), http://www.state.gov/g/drl/rls/36028.htm (accessed 12 October 2006).

29. See Joseph, Modern Assyrians, 124-25.

30. Christopher J. Walker, Armenia: The Survival of a Nation (New York: St. Martin's, 1980), 134.

31. Arnold Toynbee, "A Summary of Armenian History up to and including the Year 1915," in The Treatment of Armenians in the Ottoman Empire, 1915-1916, by James Bryce and Arnold Toynbee, ed. Ara Sarafian (Reading, UK: Taderon Press, 2000), 623.

32. Gustave Meyrier, Diplomatic Dispatch \#44, 18 December 1895, L.J., "Complete Report on the Events," quoted in Sébastien de Courtois, The Forgotten Genocide: The Eastern Christians, the Last Arameans (Piscataway, NJ: Gorgias Press, 2004), 106. During Kristallnacht, the night of 9-10 November 1938, somewhere between several dozen and 200 Jews were killed; more than 200 synagogues were burned or destroyed; 815 shops were destroyed; and 20,000 Jews were arrested. William L. Shirer, The Rise and Fall of the Third Reich (New York: Simon \& Schuster, 1960), 581-82.

33. Vahakn N. Dadrian, Warrant for Genocide: Key Elements of the Turko-Armenian Conflict (New Brunswick, NJ: Transaction Publishers, 1999), 85. "The cathedral of Urfa, the Edessa of the Crusaders, was the scene of a human holocaust, in which nearly 3,000 persons perished." William Miller, The Ottoman Empire, 1801-1913 (Cambridge: Cambridge University Press, 1913), 429.

34. Paul Cambon, Tome Premier (1870-1908): L'établissement de al République - Le Protectorat Tunisien - La régence en Espagne - La Turquie d'Abd Ul Hamid, vol. 1 of Correspondance, 1870-1924 (Paris: Grasset, 1940), 395, quoted in de Courtois, Forgotten Genocide, 110.

35. Diplomatic Dispatch \#2, Vice-Consul of Diyarbekir to Mr. Constans, French Ambassador to Constantinople, 9 January 1901, quoted in de Courtois, Forgotten Genocide, 138.

36. Ibid.

37. Ibid. Among other crimes, Kurdish chieftains had led Hamidiye in the pillage of Christian villages inhabited by Assyrians. See Diplomatic Dispatch \#17, Vice-Consul of Diyarbekir to Mr. Constans, French Ambassador to Constantinople, 13 August 1902, quoted in de Courtois, Forgotten Genocide, 144; Diplomatic Dispatch \#10, Vice-Consul of Diyarbekir to Mr. Constans, French Ambassador to Constantinople, 2 June 1904, quoted in de Courtois, Forgotten Genocide, 137; Diplomatic Dispatch \#12, Vice-Consul of Diyarbekir to Mr. Constans, French Ambassador to Constantinople, 27 July 1904, quoted in de Courtois, Forgotten Genocide, 145.

38. Diplomatic Dispatch \#6, Vice-Consul of Diyarbekir to Mr. Constans, French Ambassador to Constantinople, 9 August 1903, quoted in de Courtois, Forgotten Genocide, 143.

39. Diplomatic Dispatch \#2, Vice-Consul of Diyarbekir to Mr. Constans, French Ambassador to Constantinople, 9 January 1901, quoted in de Courtois, Forgotten Genocide, 145.

40. Diplomatic Dispatch \#21, M. Constans, French Ambassador, to M. Declasse, Minister of Foreign Affairs, 14 February 1902, quoted in de Courtois, Forgotten Genocide, 145.

41. Donald Bloxham, "The Armenian Genocide of 1915-1916: Cumulative Radicalization and the Development of a Destruction Policy," Past and Present 181 (2003): 141-91, 149.

42. Balakian, Burning Tigris, 51 .

43. Bloxham, "Armenian Genocide," 149.

44. Ibid., 151. 
45. Dadrian, Warrant for Genocide, 45, 71, 79-80, 154; Vahakn N. Dadrian, The History of the Armenian Genocide: Ethnic Conflict from the Balkans to Anatolia to the Caucasus (Providence, RI: Berghahn Books, 1995), 74, 85, 100, 107. Ultimately, the Ottoman Christians may have enjoyed more opportunistic rhetorical expressions of support than effective military or economic aid during the periods of the worst abuses. Bloxham, "Armenian Genocide," 186.

46. Balakian, Burning Tigris, 123.

47. Edward J. Erickson, Defeat in Detail: The Ottoman Army in the Balkans, 1912-1913 (Westport, CT: Praeger, 2003), xvii, xix, 3, 38, 94, 114, 121, 135-36, 240, 329.

48. Stephen Hemsley Longrigg, Iraq, 1900 to 1950: A Political, Social, and Economic History (Oxford: Oxford University Press, 1953), 41-42; Alan Palmer, The Decline and Fall of the Ottoman Empire (New York: Barnes \& Noble, 1992), 200.

49. Helen Chapin Metz, ed., Turkey: A Country Study, 5th ed. (Washington, DC: Federal Research Division, Library of Congress, 1996), ch. 1, http://countrystudies.us/turkey/ (accessed 16 October 2006).

50. Longrigg, Iraq, 43, 52, 58. Conscription of Christians began in 1909; the disarmament of Armenian soldiers and their transfer to labor battalions became the policy in February 1915.

51. "Proclamation of the Grand Council of Ulema," La Turquie, 16 November 1914), quoted in de Courtois, Forgotten Genocide, 153.

52. "Yesterday's Great March," La Turquie, 15 November 1914), quoted in de Courtois, Forgotten Genocide, 152.

53. Balakian, Burning Tigris, 169-70.

54. Jack Zakarian, The Armenian Genocide: News Accounts from the American Press: 1915-1922, ed. Richard Kloian (Richmond, CA: Anto Publishing, 1988), xiii.

55. Bryce and Toynbee, Treatment of Armenians, 135.

56. Gunter, "Kurdish Question."

57. Bryce and Toynbee, Treatment of Armenians, 14; see also vii, xii-xv, 19, 28, 33-40.

58. Ibid., $\mathrm{x}$, xiv.

59. Ibid., xv, xxi.

60. London 1916, Foreign Office Archives, 3 Class 96, Miscellaneous, Series II, six files, FO 96*205-210, cited in Thea Halo, Not Even My Name (New York: Picador, 2000), 328.

61. Ara Sarafian, introduction to The Treatment of Armenians in the Ottoman Empire, 1915-1916, by James Bryce and Arnold Toynbee, ed. Ara Sarafian, 3-13 (Reading, UK: Taderon Press, 2000), vii.

62. Halo, Not Even My Name, 328.

63. Ibid.

64. William A. Shedd, "Urmia," in The Treatment of Armenians in the Ottoman Empire, 1915-1916, by James Bryce and Arnold Toynbee, ed. Ara Sarafian, 136-41 (Reading, UK: Taderon Press, 2000), 137-39.

65. Ibid., 139.

66. Ibid.

67. Ibid.

68. It was common at the time of World War I for the British and Americans to refer interchangeably to the non-Armenian Christian population of Mesopotamia and Persia as “"Nestorians (from their religion), 'Syrians' (from their language) or Chaldeans (from their race)." Bryce and Toynbee, Treatment of Armenians, 135, 137.

69. Robert M. Labaree, "Azerbeijan, Behind the Russian Front," in The Treatment of Armenians in the Ottoman Empire, 1915-1916, by James Bryce and Arnold Toynbee, ed. Ara Sarafian, 146-49 (Reading, UK: Taderon Press, 2000), 146.

70. Jacob Sargis, "Urmia," in The Treatment of Armenians in the Ottoman Empire, 1915-1916, by James Bryce and Arnold Toynbee, ed. Ara Sarafian, 189-92 (Reading, UK: Taderon Press, 2000), 189. 
71. Y.M. Nisan, "Urmia," in The Treatment of Armenians in the Ottoman Empire, 1915-1916, by James Bryce and Arnold Toynbee, ed. Ara Sarafian, 187-89 (Reading, UK: Taderon Press, 2000), 187.

72. Sargis, "Urmia," 191.

73. Shedd, "Urmia,"137-39.

74. F.N. Jessup, "Tabriz," in The Treatment of Armenians in the Ottoman Empire, 1915-1916, by James Bryce and Arnold Toynbee, ed. Ara Sarafian, 149-54 (Reading, UK: Taderon Press, 2000), 153.

75. Labaree, "Azerbeijan," 146.

76. Sargis, "Urmia," 189. Gulpashan was "wholly ransacked," the men slaughtered and the attractive women kidnapped. Yohannan, Death of a Nation, 127.

77. Jessup, “Tabriz," 152-53.

78. Ara Sarafian, ed., United States Official Documents on the Armenian Genocide, vol. 2 (Watertown, MA: Armenian Review Press, 1994), 144.

79. Sarafian, US Official Documents, vol. 2, 135.

80. Eugène Griselle, Syriens et Chaldéens, Leur Martyre, Leurs Espérances (Paris: Bloud et Gay, 1918), 19-22; Basile M. Nikitine, "Une petite nation victime de la guerre," Revue des sciences politiques 44 (1921): 602-24; Basile M. Nikitine, "La Vie domestique des Assyro-Chaldéens du Plateau d'Ourmiah," Société d'ethnographie de Paris.

Ethnographie (1925): 356-81; Browne, "The Assyrians"; Joseph Alichoran, "AssyroChaldeans in the 20th Century: From Genocide to Diaspora," Journal of Assyrian Academic Studies 8 (1994): 45-79.

81. Johannes Lepsius, Deutschland und Armenien, 1914-1916 (Potsdam: Tempelverlag, 1919), quoted in Gabriele Yonan, Ein vergessener Holocaust: Die Vernichtung der christlichen Assyrer in der Türkei (Göttingen: Gesellschaft für bedrohte Völker, 1989), 270.

82. Bryce and Toynbee, Treatment of Armenians, ch. 2, http://www.lib.byu.edu/ rdh/wwi/ 1915/bryce/a02.htm\#II (accessed 12 October 2006).

83. Ibid., ch. 3, http://www.lib.byu.edu/ rdh/wwi/1915/bryce/a04.htm (accessed 12 October 2006); Griselle, Syriens et Chaldéens, 23-26; "The Assassination of a Race," The Independent, 18 October 1915.

84. Bryce and Toynbee, ibid.

85. See Griselle, Syriens et Chaldéens, 23-26.

86. Labaree, "Azerbeijan," 147.

87. Ibid.

88. Joseph Tfinkdji, The Victims of the Chaldean Nation during the Massacres in Armenia: Report of a Chaldean Clergyman (St. Pichon, 1918), quoted in Yonan, Ein vergessener Holocaust, 309-12; Father Dakras, "What Father Dakras Saw of Massacres in Turkey," Washington Post, 28 November 1915, M5.

89. Dakras, ibid.

90. Yusuf Malek, The British Betrayal of the Assyrians (Warren Point, NJ: Kimball Press, 1936), ch. 18, http://www.aina.org/books/bbota.htm (accessed 12 October 2006).

91. Longrigg, Iraq, 97; Coakley, Church of the East, 337.

92. Sarafian, US Official Documents, vol. 2, 137.

93. Ibid.

94. H.P. Packard, letter to the editor, New York Times, 18 September 1916, 12, http:// web.archive.org/web/20010708193304/www.atour.com/ history/ny-times/20001126g.html (accessed 19 October 2006).

95. Sarafian, US Official Documents, vol. 2, 142-43.

96. Baum and Winkler, Church of the East, 137.

97. Paul Shimmon, "Hakkiari," in The Treatment of Armenians in the Ottoman Empire, 1915-1916, by James Bryce and Arnold Toynbee, ed. Ara Sarafian, 200-203 (Reading, UK: Taderon Press, 2000), 201. 
98. Alpheus N. Andrus, "Mardin," in "Turkish Atrocities": Statements of American Missionaries on the Destruction of Christian Communities in Turkey, 1915-1917, ed. James L. Barton, 100-101 (Ann Arbor, MI: Gomidas Institute, 1998), 100-101.

99. Shimmon, "Hakkiari," 201.

100. Walker, Armenia, 215.

101. Shimmon, "Hakkiari," 201.

102. Ibid.

103. Lepsius, Deutschland und Armenien, quoted in Yonan, Ein vergessener Holocaust, 270.

104. Longrigg, Iraq, 97.

105. Ibid., 98.

106. "Bishops Appeal for Nestorians," New York Times, 13 November 1916, 13.

107. Baum and Winkler, A Concise History, 137, 139.

108. Parliamentary Debates, Lords, 5th ser., vol. 90 (1933-34), p. 142, quoted in The Assyrian Tragedy (1934), http://www.aina.org/books/tat.htm (accessed 12 October 2006).

109. Baum and Winkler, A Concise History, 137, 139; Efraim Karsh and Inari Karsh, Empires of the Sand: The Struggle for Mastery in the Middle East, 1789-1923 (Cambridge, MA: Harvard University Press, 2001), 160.

110. R.S. Stafford, "Iraq and the Problem of the Assyrians," International Affairs 13 (1934): 159-85, 164.

111. George Seldes, "Chaldeans Outraged as Massacred by Turks," Los Angeles Times, 25 October 1925, 1.

112. Lamsa and Emhardt, Oldest Christian People, 131.

113. The Settlement of the Assyrians, A Work of Humanity and Appeasement (Geneva: League of Nations, 1935), 9, quoted in Joseph Yacoub, The Assyrian Question (Chicago: Alpha Graphic, 1986), 8.

114. Baum and Winkler, A Concise History, 144-45.

115. See, e.g., Bryce and Toynbee, Treatment of Armenians; "Wholesale Massacres of Armenians by Turks," New York Times, 29 July 1915; "Armenians Dying in Prison Camps," New York Times, 21 August 1915; "500,000 Armenians Said to Have Perished," New York Times, 24 September 1915; "800,000 Armenians Counted Destroyed," New York Times, 7 October 1915; "Armenian Refugees Reach New York. Driven from Their Homes by Turks Last July," Los Angeles Times, 9 March 1916, I-2; William Walker Rockwell, "The Total of Armenian and Syrian Dead," Current History: A Monthly Magazine of the New York Times, November 1916, 337-38, http:// www.cilicia.com/armo10c-nyt191611b.html (accessed 13 October 2006); "Morgenthau Urges Carving of Turkey," Los Angeles Times, 12 December 1918, I-1; "Millions of Armenians Starving in Turkey. American Relief Expedition To Sail Next Month To Relieve Suffering," Los Angeles Times, 26 December 1918, I-2; "Hoover Pleads for Armenians," Los Angeles Times, 12 January 1919, II-9; George R. Montgomery, "The Massacres of Armenians in 1915," Current History Magazine, October 1922, 25-28, http://www.cilicia.com/armo10c-nyt192210b.html (accessed 19 October 2006).

116. "Turks Slaughter Greeks, Sell Women to Slavery," Los Angeles Times, 9 June 1918.

117. R.J. Rummel, Death by Government (London: Transaction Publishers, 1994), 229, 234.

118. "Turks Slaughter Greeks."

119. Rummel, Death by Government, 229; Rockwell, "Total of Armenian," 338 (80,000 to 120,000 starved to death in Lebanon and Syria).

120. James Bryce, preface to Shall This Nation Die? by Joseph Naayem (New York: Chaldean Rescue, 1921), http://www.lulu.com/items/volume_2/140000/140495/2/preview/ Naayem_Preview.pdf (accessed 12 October 2006).

121. Henry I. Morgenthau, Ambassador Morgenthau's Story (Garden City, NY: Doubleday, Page \& Co., 1918; reprint, Reading, UK: Taderon Press, 2000), 214; also see online edition, 
http://web.archive.org/web/20040202000014/http://www.cilicia.com/morgenthau/ Morgen24.htm (accessed 19 October 2006).

122. Ibid.

123. "Morgenthau Urges," I-1.

124. Ara Sarafian, ed., United States Official Documents on the Armenian Genocide, vol. 1 (Watertown, MA: Armenian Review Press, 1993), 54.

125. Ibid., 48-49.

126. Ibid.

127. Leslie A. Davis, The Slaughterhouse Province: An American Diplomat's Report on the Armenian Genocide (New Rochelle, NY: Caratzas, 1990), 144-45.

128. Ibid.

129. Ibid.

130. DE/PA-AA/R14086, 1915-A-23244, No. 477, report from Ernst Langenburg Hohenlohe, German Ambassador in Constantinople, to Chancellor Bethmann Hollweg, dated 31 July 1915, http://www.armenocide.de/armenocide/armgende.nsf/3f23b353912a55f8 c1256ad7006edaff/333eb1a5ff7f9ebec12568f30059b1d5?OpenDocument (accessed 19 October 2006).

131. DE/PA-AA/Bo.Kons./Band 169, No. 11, telegram from Walter Holstein, Vice-Consul of Mosul, to German Embassy in Istanbul, dated 15 July 1915, http://www.armenocide.de/ armenocide/armgende.nsf/0/63866a0769f240cbc12568f30059b1c3?OpenDocument (accessed 19 October 2006).

132. DE/PA-AA/Bo.Kons./Band 169, No. 14, telegram from Walter Holstein, Vice-Consul of Mosul, to German Embassy in Istanbul, dated 21 July 1915, http://www.armenocide.de/ armenocide/armgende.nsf/60ab487bce875307c1256d000047d055/ 157fa8e809878c2cc12568f30059b1cd?OpenDocument (accessed 19 October 2006).

133. DE/PA-AA/Bo.Kons./Band 170, A53a/1915/5779, report of Rössler, German Consul in Aleppo, to Ernst Langenburg Hohenlohe, Ambassador on Extraordinary Mission in Constantinople,, dated 27 September 1915, http://www.armenocide.de/armenocide/ armgende.nsf/1609e6f136e68c36c1256b330009af75/fe3cd5f683fb1e13c12568f30059b221? OpenDocument (trans. Vera Draack; accessed 19 October 2006).

134. DE/PA-AA/R14087, K. No. 90/B. No. 1950, telegram from Rössler, German Consul in Aleppo, to German Chancellor Bethmann Hollweg, dated 3 September 1915, http://www. armenocide.de/armenocide/armgende.nsf/74c6b7b259a64ecdc1256b320083617c/ f6d8f87cf678fb7bc12568f30059b207?OpenDocument (accessed 19 October 2006).

135. Vahakn N. Dadrian, "Documentation of the Armenian Genocide in German and Austrian Sources," in The Widening Circle of Genocide: A Critical Bibliographic Review, ed. Israel W. Charny, 77-126 (New Brunswick, NJ: Transaction Publishers, 1994), 100, 101, 124.

136. Yair Auron, Zionism and the Armenian Genocide: The Banality of Indifference (New Brunswick, NJ: Transaction Publishers, 2003), 49.

137. Ibid., 50. The Germans condemned the "massive and indiscriminate expulsions... accompanied by acts of violence such as massacres and pillages." Dadrian, "Documentation," 98.

138. Dadrian, "Documentation," 100.

139. Johannes Lepsius, Report on the Condition of the Armenian People (Potsdam, 1916), and Johannes Lepsius, Collection of Diplomatic Files (Potsdam, 1919), both cited in Gabriele Yonan, "Holy War Made in Germany: New Light on the Holocaust against the Christian Assyrians during World War I," paper presented at the international conference Assyrians After Assyria: Persecutions and Massacres of Syriac-speaking Christians, University of Sydney, Australia, 2 July 2000, http://www.nineveh.com/ Holy\%20War\%20Made\%20in\%20Germany.html (accessed 13 October 2006).

140. Vahakn N. Dadrian, German Responsibility in the Armenian Genocide: A Review of the Historical Evidence of German Complicity (Cambridge, MA: Blue Crane Books, 1996).

141. "Syrian Tells of Atrocities," Los Angeles Times, 15 December 1918, I-1. 
142. "Native Christians Massacred; Frightful Atrocities in Persia," Los Angeles Times, 2 April 1915, I-1.

143. Ibid.

144. Ibid. The Washington Post published a similar report: "Turks Kill Hundreds," Washington Post, 2 April 1915, 1. A book published in the United States after the war cited a letter describing 750 dead Christians and 500 kidnapped Christian girls in Hafdewan. Yohannan, Death of a Nation, 127.

145. "More Violence by Turks," Los Angeles Times, 27 March 1915, II-1.

146. "People Flee From Kurds," Los Angeles Times, 3 May 1915, I-2.

147. Ibid.

148. "Turkish Horrors in Persia," New York Times, 11 October 1915, http://www.cilicia.com/ armo10c-nyt19151011d.html (accessed 13 October 2006).

149. "Chaldean Victims of the Turks," Times (London), 22 November 1919, 11

150. Uwe Siemon-Netto, "Terror Fallout Hurts Iraqi Christians," United Press International, 5 November 2001, http://www.atour.org/news20.htm (accessed 1 March 2006); Uwe Siemon-Netto, "Attacks Defy the Prophet's Wish," Washington Times, 3 August 2004, http://washingtontimes.com/upi-breaking/20040803-1014318900r.htm (accessed 1 March 2006); Yonan, Ein vergessener Holocaust, 251-313; Yonan, "Holy War"; Richard P. McBrien, ed., The HarperCollins Encyclopedia of Catholicism (New York: HarperCollins, 1995); "The Claims of the Assyrians Before the Conference of the Preliminaries of Peace at Paris, 1919," in The Flickering Light of Asia, or The Assyrian Nation and Church, by Joel E. Werda (Chicago: Author, 1924), http://www.aina.org/books/fla/fla.htm\#c31 (accessed 13 October 2006); Franca Arena, “Assyrian Oppression," Legislative Council Papers, New South Wales, 14 September 1993, http://www.parliament.nsw.gov.au/prod/parlment/hansart.nsf/V3Key/LC19930914036 (accessed 13 October 2006), art. 36; Lewis, "Iraqi Assyrians."

151. "Urumiah Massacres. Death of 12,000 Nestorian Christians," Times (London), 9 October 1915.

152. Ibid.

153. Ibid.

154. Ibid.

155. "Assyrians' War Sufferings," Times (London), 15 June 1920.

156. "Chaldean Victims."

157. "Massacres Kept Up," Washington Post, 26 March 1915, 1.

158. "40 Die Daily in Mission," Washington Post, 11 April 1915, R4.

159. Ibid.

160. "Massacred by Kurds; Christians Unable to Flee from Urmia Put to Death," Washington Post, 14 March 1915, 10.

161. Ibid.

162. Yonan H. Shahbaz, The Rage of Islam: An Account of the Massacre of Christians by the Turks in Persia (Philadelphia: Roger Williams Press, 1918), 94.

163. "Christians in Danger; Fearing New Massacre by Kurds, State Department Acts," Washington Post, 27 March 1915, 1.

164. Yonan H. Shahbaz, The Rage of Islam: An Account of the Massacre of Christians by the Turks in Persia (Philadelphia: Roger Williams Press, 1918), 170-71. For an account of how this extraordinary individual of Assyrian descent became an American missionary and endured incredible travails to write his story, see Robert Stuart MacArthur, introduction to The Rage of Islam: An Account of the Massacre of Christians by the Turks in Persia, by Yonan H. Shahbaz (Philadelphia: Roger Williams Press, 1918), vii-xi. The author calls the Christians of Persia and Mesopotamia "Nestorian" but clarifies that most of them preferred to be called Assyrians. Shahbaz, Rage of Islam, 24.

165. Ibid., 57.

166. Ibid., 161. 
167. See "Cheap at the Price," Times (London), 26 May 2006, http://property.timesonline.co.uk/ article/0,,14052-2193897,00.html (accessed 19 October 2006).

168. Republic of Turkey, Directorate General of Press and Information, "The Armenian Allegation of Genocide: Facts" (2001), http://www.byegm.gov.tr/yayinlarimiz/newspot/ 2001/mar_apr/n5.htm (accessed 17 February 2006).

169. Hasan Köni and Kemal Çiçek, "The Relocation of the Armenians during the WWI" (April 2005), http://www.ttk.gov.tr/ingilizce/armenian_studies/april2005-2.pdf (accessed 13 October 2006), 5 .

170. Ibid.

171. Ibid.

172. Ibid.

173. "Armenian Massacres of 1915," Parliamentary Debates, Lords, 6th ser., vol. 599 (29 March-22 April 1999), col. 1212, answer by Lord Triesman, Parliamentary Under-Secretary of State, Foreign and Commonwealth Office, to question by Baroness Cox to the government, http://www.publications.parliament.uk/pa/ld200506/ldhansrd/ vo050714/text/50714-01.htm (accessed 19 October 2006).

174. Convention on the Prevention and Punishment of the Crime of Genocide, 9 December 1948, 78 U.N.T.S. 277, http://www.unhchr.ch/html/menu3/b/p_genoci.htm (accessed 13 October 2006), art. 2.

175. Ibid., emphasis added; Yoram Dinstein, War, Aggression and Self-Defence, 3rd ed. (Cambridge: Cambridge University Press, 2001), 108.

176. Trial of the Major War Criminals before the International Military Tribunal, Nuremberg, 14 November 1945-10 October 1946, vol. 1 (1947), 43-44, cited in Elizabeth Borgward, "Re-examining Nuremberg as a New Deal Institution: Politics, Culture and the Limits of Law in Generating Human Rights Norms," Berkeley Journal of International Law 23 (2005): 42-68, 401.

177. "Reservations to the Convention on the Prevention of Genocide" (advisory opinion), ICJ Reports 1951: 15-55, 21-22, 23-24.

178. Benjamin Whitaker, "Revised and Updated Report on the Question of the Prevention and Punishment of the Crime of Genocide," E/CN.4/Sub.2/1985/6 (UN Economic and Social Council, Commission on Human Rights, Sub-commission on Prevention of Discrimination and Protection of Minorities, 2 July 1985).

179. Statute of the International Court of Justice, 24 October 1945, 59 Stat. 1031, 1060; T.S. No. 993, 25, arts. 36 (2)(a-d), 38 (1)(a-d), http://www.icj-cij.org/icjwww/ibasicdocuments/ ibasictext/ibasicstatute.htm (accessed 13 October 2006), art. 36(2)(a-d), art. 38(1)(a-d); Peter Malanczuk, Akehurst's Modern Introduction to International Law (London: Routledge, 1997), 39, states that sources of international customary law include "newspaper reports of actions taken by states, and... statements made by government spokesmen ... laws and judicial decisions ... extracts from [Foreign Ministry] archives ... the writings of international lawyers ...judgments of national and international tribunals ... treaties ... nonbinding resolutions and declarations."

180. For example, as early as the fourteenth century, an English court tried and convicted the Scottish rebel William Wallace for waging war in an illegal manner, "sparing neither age nor sex, monk nor nun." Timothy L.H. McCormack, "Selective Reaction to Atrocity: War Crimes and the Development of International Criminal Law," Albany Law Review 60 (1997): 681-732, 689. In the fifteenth century, a warrior in the service of the Duke of Burgundy was tried and convicted for murder and rape committed during the occupation of Austria, in violation of the "laws of God and man." Ibid., 690. In the seventeenth century, the King of Sweden decreed Articles of War that, among other things, declared that any attempt to "tyrannise over" unarmed men, women, or children, particularly clergy and aged people, would be made under pain of "punishment at the discretion of the Judges." Kenneth Ögren, "Humanitarian Law in the Articles of War Decreed in 1621 by King Gustavus II Adolphus of Sweden," International Review of the Red Cross 313 (1996): 438-42, http://www.icrc.org/Web/Eng/siteeng0.nsf/iwpList154/ 
BC396F38899D10BEC1256B66005A2479 (accessed 13 October 2006).

Seventeenth-century English law similarly banned attacks on civilians or prisoners of war. Will Coster, "Massacre and Codes of Conduct during the English Civil War," in The Massacre in History, ed. Mark Levene and Penny Roberts, 89-106 (New York: Berghahn Books, 1999), 96; McCormack, "Selective Reaction to Atrocity," 692-93. In the eighteenth century, famed international jurist Emmerich de Vattel wrote that a state that robs, murders, or ill-treats the subjects of another sovereign, or that persecutes its own religious minorities, is a "common enemy of the human race" that all nations are entitled to sanction. Emmerich de Vattel, Le droit des gens, ou Principes de la loi naturelle (1758), trans. Charles G. Fenwick (Washington, DC: Carnegie Institution, 1916), 131-37, quoted in Leslie Green, "New Trends in International Criminal Law," Israel Year Book on Human Rights 11 (1981): 9-40, 11-12. In the nineteenth century, European powers tried and convicted Napoleon Bonaparte for waging unjust wars. Gary Jonathan Bass, Stay the Hand of Vengeance: The Politics of War Crimes Tribunals (Princeton, NJ: Princeton University Press, 2000), 37-57; Jon Elster, Closing the Books: Transitional Justice in Historical Perspective (Cambridge: Cambridge University Press, 2004), 3-76. Also in the nineteenth century, the United States tried and convicted British nationals for massacring women and children in violation of "the law of nations" and "the laws and usages of war." McCormack, "Selective Reaction to Atrocity," 694.

181. Convention (No. IV) Respecting the Laws and Customs of War on Land, with Annex of Regulations, 19 October 1908, 36 Stat. 2277, T.S. 539, 1 Bevans 631, 1907 U.S.T. LEXIS 29, art. 46 .

182. Ibid.

183. Dinstein, War, Aggression, 108. Even before Nuremberg, the Entente cited the Hague Convention to justify "individual war crimes prosecutions" against "leading members of the ... Young Turks" thought "to be responsible for the massacre of hundreds of thousands of Armenians perpetrated under the guise of wartime deportations." M. Cherif Bassiouni, "World War I: 'The War to End All Wars' and the Birth of a Handicapped International Criminal Justice System,” Denver Journal of International Law and Policy 30 (2002): 244-96, 244.

184. "Declaration by the Governments of France, Great Britain and Russia" (29 May 1915), in United Nations War Crimes Commission, History of the United Nations War Crimes Commission and the Development of the Laws of War (London: HMSO, 1948), 35, http:// www.armenian-genocide.org/popup/affirmation_window.html?Affirmation $=160$ (accessed 13 October 2006).

185. Ibid.

186. Vahakn N. Dadrian, "The Armenian Genocide and the Legal and Political Issues in the Failure to Prevent or to Punish the Crime," University of West Los Angeles Law Review 29 (1998): 43-78, 57.

187. John Shamsey, "Comment: 80 Years Too Late: The International Criminal Court and the 20th Century's First Genocide," Journal of Transnational Law and Policy 11 (2002): 327-83, 336, 340-41.

188. Ibid., 348, quoting Vartkes Yeghiayan, The Armenian Genocide and the Trials of the Young Turks (La Verne, CA: American Armenian International College Press, 1990), xxvi.

189. "Turkey Condemns Its War Leaders: Court-Martial Gives Death Sentence to Enver Pasha, Tallat Bey, and Djemal Pasha," New York Times, 13 July 1919, http://www.cilicia.com/ armo10c-nyt19190713.html (accessed 13 October 2006).

190. Vahakn N. Dadrian, "The Turkish Military Tribunal's Prosecution of the Authors of the Armenian Genocide: Four Major Court-Martial Series," Holocaust and Genocide Studies 7 (1997): 28-59, 34.

191. Emile Hildebrand, "Kemal Promises More Hangings of Political Antagonists in Turkey," Los Angeles Examiner, 1 August 1926, quoted in Dennis R. Papazian, 
"Misplaced Credulity: Contemporary Turkish Attempts to Refute the Armenian Genocide," Armenian Review 45 (1992): 185-213.

192. Treaty of Peace Between the Allied Powers and Turkey (Treaty of Sèvres), 10 August 1920 (unratified), arts. 142, 144, reprinted in American Journal of International Law 15 (Supplement: Official Documents, 1921): 179-295.

193. Ibid., arts. $27,140-41,145,147-50$, reprint pp. 182-84, 208-9, 211-12.

194. Ibid., art. 230.

195. Shamsey, "80 Years Too Late," 271-72.

196. Dadrian, "Turkish Military Tribunal's Prosecution," 51-52.

197. Dadrian, History of the Armenian Genocide, 332-35, 340-41.

198. Merrill D. Peterson, Starving Armenians: America and the Armenian Genocide, 1915-1930 and After (Charlottesville: University of Virginia Press, 2004); 134-35; Hans Köchler, Global Justice or Global Revenge? International Criminal Justice at the Crossroads (New York: Springer-Verlag, 2004), 58; Dadrian, History of the Armenian Genocide, 333, 341; M. Cherif Bassiouni, "From Versailles to Rwanda in Seventy-Five Years: The Need to Establish a Permanent International Criminal Court," Harvard Human Rights Journal 10 (1997): 11-62, 17.

199. Republic of Turkey, "Armenian Allegation of Genocide."

200. Ibid.

201. “Armenian Massacre, 1915," Parliamentary Debates, Lords, 6th ser., vol. 599 (29 March22 April 1999), col. 826, answer by Baroness Ramsay of Cartvale to question by Baroness Cox to the government, http://www.publications.parliament.uk/pa/ld199899/ldhansrd/ vo990414/text/90414-09.htm (accessed 13 October 2006).

202. "Genocide as a form of state crime has required a cooperative endeavor by individuals operating on many different levels of the state, with dramatically different orientations, objectives and motivations." David O. Friedrichs, "The Crime of the Century? The Case for the Holocaust," Crime, Law and Social Change 34 (2000): 21-41, 29.

203. Morgenthau, Ambassador Morgenthau's Story, 10, 20, 34.

204. Halo, Not Even My Name, 126.

205. Panayiotis Diamadis, "The Assyrian in the Christian Asia Minor Holocaust," paper presented at the international conference Assyrians After Assyria: Persecutions and Massacres of Syriac-speaking Christians, University of Sydney, Australia, 2 July 2000, http://aanf.org/America/assyrians/assyrian_christian.htm (accessed 13 October 2006).

206. Ibid.

207. Bloxham, "Armenian Genocide," 156-57.

208. Ibid., 157.

209. Ibid.

210. Shahbaz, The Rage of Islam, 51-53.

211. Sarafian, US Official Documents, vol. 2, 137.

212. James L. Barton, Story of Near East Relief (1915-1930) (New York: Macmillan, 1930), 91.

213. Bloxham, "Armenian Genocide," 152.

214. Ibid.

215. Ibid.

216. Dadrian, "Documentation of the Armenian Genocide," 99.

217. Morgenthau, Ambassador Morgenthau's Story, 34.

218. Ibid., 193.

219. DE/PA-AA/R14086, A-19743, report from Wangenheim, Ambassador in Constantinople to Reichskanzler Bethmann Hollweg, 24 June 1915, http://www.armenocide.de/ armenocide/armgende.nsf/1609e6f136e68c36c1256b330009af75/ ecd802ded50a4089c12568f30059b196?OpenDocument (accessed 13 October 2006).

220. Johannes Lepsius, Bericht uber die Lage des Armenischen Volkes in der Turkei (Postdam, 1916), quoted in Yonan, Ein vergessener Holocaust, 248; see also Morgenthau, Ambassador Morgenthau's Story, 243; Bryce and Toynbee, Treatment of the Armenians, ch. 2, http:// www.lib.byu.edu/ rdh/wwi/1915/bryce/a03.htm (accessed 13 October 2006). 
221. Yves Ternon, "Report on the Genocide of the Armenians of the Ottoman Empire, 1915-1916," in A Crime of Silence: The Genocide of the Armenians, ed. Gerard Libaridian, 61-93 (London: Zed Books, 1985).

222. Bloxham, "Armenian Genocide," 152.

223. "Defense Committee Corners Supplies," New York Times, 13 September 1915, http:// www.umd.umich.edu/dept/armenian/facts/islam.html (accessed 13 October 2006).

224. Yonan, Ein vergessener Holocaust, 99.

225. Johannes Lepsius, Deutschland und Armenien, quoted in Yonan, Ein vergessener Holocaust, 269.

226. Ibid., 270.

227. Bloxham, "Armenian Genocide," 142.

228. Balakian, Burning Tigris, 286.

229. As the Appeals Chamber for the International Criminal Tribunal for Rwanda recently held,

The Tribunal's jurisprudence conclusively establishes that genocidal intent can be proven through inference from the facts and circumstances of a case. By its nature, intent is not usually susceptible to direct proof. Only the accused himself has firsthand knowledge of his own mental state, and he is unlikely to testify to his own genocidal intent. Intent thus must usually be inferred...

Evidence of genocidal intent can be inferred from "the physical targeting of the group or their property; the use of derogatory language toward members of the targeted group; the weapons employed and the extent of bodily injury; the methodical way of planning, the systematic manner of killing."

Prosecutor v. Gacumbitsi, Judgment, ICTR-2001-64-A (7 July 2006), 15, para. 40, http:// 69.94.11.53/ENGLISH/cases/Gachumbitsi/judgement/judgement_appeals_070706.pdf (accessed 13 October 2006) [Gacumbitsi Appeals Judgment].

230. Prosecutor v. Akayesu, Judgment, ICTR-96-4-T (2 September 1998) [Akayesu Trial Judgment], quoted in Prosecutor v. Jelisic, Judgment, IT-95-10-A (5 July 2001), http:// www.un.org/icty/Supplement/supp26-e/jelisic.htm (accessed 13 October 2006) [Jelisic Appeals Judgment].

231. Ibid.

232. Ibid.

233. Akayesu Trial Judgment, paras. 698-734; Karen Engle, "Feminism and Its (Dis)Contents: Criminalizing Wartime Rape in Bosnia and Herzegovina," American Journal of International Law 99 (2005): 778-816, 791-94; Rosalind Dixon, "Rape as a Crime in International Law: Where to Go from Here?" European Journal of International Law 13 (2002): 697-719, 703-4.

234. Israel (Prosecutor General) v. Eichmann, Jerusalem District Court (12 December 1961), in International Law Reports 36 (1968): 340. At least two former Soviet republics, Latvia and Estonia, have convicted Communist-era officials for genocide based on evidence that they deported members of ethnic or national groups with the intent to destroy the group in part. Lauri Mälksoo, "Soviet Genocide? Communist Mass Deportations in the Baltic States and International Law," Leiden Journal of International Law 14 (2001): 757-87, 774-78, 780.

235. "Genocide means any of the following acts committed with intent to destroy, in whole or in part, a national, ethnical, racial or religious group, as such:...(c) Deliberately inflicting on the group conditions of life calculated to bring about its physical destruction in whole or in part..." UNCG, art. 2. The phrase "deliberate inflicting on the group conditions of life calculated to bring about its physical destruction, in whole or part," includes, among other acts, "systematic expulsion from homes." Akayesu Trial Judgment, paras. 507-8. International tribunals infer genocidal intent from patterns of such acts that tend to "violate the very foundation of the group." Prosecutor v. Karadzic and Mladic, 
Review of the Indictments Pursuant to Rule 61 of the Rules of Procedure and Evidence, IT-95-5-R61-T and IT-95-18-R61-T (16 July 1996), para. 94. Thus, "attacks on the cultural and religious property and symbols of the targeted group ... may legitimately be considered as evidence of an intent to physically destroy the group." Prosecutor $v$. Krstic, Judgment, IT-98-33-T (2 August 2001), para. 580, http://www.worldlii.org/int/cases/ICTY/2001/8.html (accessed 13 October 2006) [Krstic Trial Judgment].

236. Krstic Trial Judgment, para. 513.

237. UNCG, art. 2.

238. Raphael Lemkin, Axis Rule in Occupied Europe: Laws of Occupation, Analysis of Government, Proposals for Redress (Washington, DC: Carnegie Endowment for International Peace, 1944), 79.

239. Ibid.

240. Only Reagan, Ford, and Bush actually used the term "genocide," Carter preferring to speak of "eliminat[ion]." Rep. Michael Bilrakis, "Commemorating Armenian Genocide," 107th Cong., 1st sess., Congressional Record 147 (24 April 2001): H1518-19; President Ronald Reagan, "Days of Remembrance of Victims of the Holocaust," 101st Cong., 2nd sess., Congressional Record 136 (22 April 1981): S1438-39; Fergal Keane, "Armenians Say US Failed Them," BBC News, 26 January 2003), http://news.bbc.co.uk/1/hi/ programmes/correspondent/2572667.stm (accessed 13 October 2006); Armenian National Committee of America, "Quotes," 2004, http://www.anca.org/genocide/quotes.php (accessed 13 October 2006).

241. Warren Tolman and Dikran Kaligian, "It's Elementary: Turks Committed Genocide," Boston Herald, 9 December 2005, 33.

242. Jason Wermers, "Massacres Genocide? 23 States Have Legislation That Recognizes Stance of Armenians," Richmond Times Dispatch, 2 April 2001, B1.

243. "Armenian Massacre, 1915," Parliamentary Debates, Lords, 6th ser., vol. 599 (29 March-22 April 1999), col. 811, question by Baroness Cox to the government, http:// www.publications.parliament.uk/pa/ld199899/ldhansrd/vo990414/text/90414-08.htm (accessed 13 October 2006); “Turkey Protests 'Genocide' Reference,” Catholic Insight 9, 10 (December 2001): 23.

244. “Turkey 'Must Admit Armenia Dead," BBC News, 13 December 2004, http://news. bbc.co.uk/2/hi/europe/4092933.stm (accessed 13 October 2006).

245. Ibid.

246. "Armenian Massacre, 1915," Parliamentary Debates, Lords; "US House Committee to Discuss Genocide Resolution," Turkish Daily News, 9 September 2005; "Swiss Accept Armenia “Genocide,” BBC News, 16 December 2003, http://news.bbc.co.uk/2/hi/europe/ 3325247.stm (accessed 13 October 2006).

247. Afram Barryakoub, "Academic Conference on Seyfo Held in Sweden," Zinda Magazine, 19 November 2005, http://www.zindamagazine.com/html/archives/2005/11.19.05/index sat.php (accessed 13 October 2006).

248. As a prominent scholar of the Armenian genocide stated upon being asked whether the Armenian parliament should recognize the Assyrian genocide, "we do not know much about your experience." Ibid.

249. Vahakn Dadrian has compiled much of the extant evidence of Ottoman admissions of genocidal intent to exterminate the Armenians in particular, although much of this evidence also supports an intention to wipe out or "cleanse" Ottoman Christians more broadly. Dadrian, History of the Armenian Genocide, 219-48; Dadrian, Warrant for Genocide, 85-105, 123-33; Dadrian, German Responsibility; Dadrian, "Documentation of the Armenian Genocide," 98-101; Dadrian, "Turkish Military Tribunal's Prosecution," 35, 38-39, 43, 48, 54, 51-52; Dadrian, "Armenian Genocide"; Vahakn N. Dadrian, "The Naim-Andonian Documents on the World War I Destruction of Ottoman Armenians: The Anatomy of a Genocide," International Journal of Middle East Studies 18 (1986): 311-60; Vahakn N. Dadrian, "The Documentation of the World War I Armenian Massacres in the Proceedings of the Turkish Military Tribunal," International Journal 
of Middle East Studies 23 (1991): 549-76, 558; Vahakn N. Dadrian, "Documentation of the Armenian Genocide in Turkish Sources," in Genocide: A Critical Bibliographic Review, ed. Israel W. Charny, 86-138 (New York: Facts On File, 1991); Vakahn N. Dadrian, "The Secret Young-Turk Ittihadist Conference and the Decision for the World War I Genocide of the Armenians," Holocaust and Genocide Studies 7 (1993): 173-201.

250. The International Criminal Tribunal for Rwanda, for example, found the requisite genocidal intent in a case bearing some similarities to the massacres of Assyrians in northern Mesopotamia and Persia, noting that "explicit manifestations of criminal intent are, for obvious reasons, often rare in the context of criminal trials," and that to "prevent perpetrators from escaping convictions simply because such manifestations are absent, the requisite intent may normally be inferred from relevant facts and circumstances." Prosecutor v. Kayishema and Ruzindana, Judgment, ICTR-95-1-A (1 June 2001), http:// 65.18.216.88/ENGLISH/cases/KayRuz/appeal/3d.htm (accessed 1 March 2006), para. 159. The Tribunal found to be adequate evidence of intent the facts that the defendant transported attackers to sites of violent conflict, "directed attackers to kill and offered payment in exchange for the severed heads of well known Tutsis or identification cards of murdered Tutsis," carried weapons, and was believed to be purchasing weapons for attackers. Ibid., para. 158.

251. Prosecutor $v$. Milosevic, Decision on Motion for Judgement of Acquittal, IT-02-54-T (16 June 2004), http://www.un.org/icty/milosevic/trialc/judgement/040616.htm (accessed 13 October 2006), para. 120, citing Jelisic Appeals Judgment, para. 37, citing Akayesu Trial Judgment, paras. 698-734.

252. UN, Committee on the Elimination of Racial Discrimination, Summary Record of the 1530th Meeting, CERD/C/SR.1530, 14 August 2002, http://www.unhchr.ch/tbs/ doc.nsf/0/81d55fc0366b053cc1256c17002f1a16/\%24FILE/G0243887.doc (accessed 13 October 2006); Lyden, "Despite Turmoil”; Sabrina Tavernise, "In a Muslim City in Iraq."

253. CIA World Factbook: Armenia (2006), https://www.cia.gov/cia/publications/factbook/geos/ am.html (accessed 13 October 2006). The British government has estimated that about 1.5 million Christians lived in Iraq before the 2003 war. UK, Home Office, Country Assessment: Iraq (October 2001), http://www.asylumlaw.org/docs/showDocument. cfm?documentID=844 (accessed 13 October 2006); Danish Immigration Service, "Joint British-Danish Fact Finding Mission to Damascus, Amman, and Geneva Regarding Iraqi Asylum Seekers" (June 2002), http://www.unhcr.org/cgi-bin/texis/vtx/ home/opendoc.pdf?tbl=RSDCOI\&id=3f4908364 (accessed 13 October 2006). The US media also frequently reports that up to 1.5 million Christians live in Iraq. Patrick McDonnell, "After Years of Relative Peace, Christians Live in Fear," Los Angeles Times, 15 November 2004, http://www.armeniandiaspora.com/archive/14453.html (accessed 13 October 2006). The 1987 census in Iraq revealed a population of 1.4 million Christians. Daniel Pipes, "Ethnic Cleansing of Iraq's Christians," Human Events, 24 August 2004, http://www.humaneventsonline.com/article.php?id=4865 (accessed 13 October 2006). Various estimates over the years have counted 600,000 Iraqis as Chaldean Catholics; 300,000 to 500,000 as Assyrians (Church of the East); and 140,000 as Orthodox Christians. "Patriarch Raphael I Bidawid," Times (London), 29 July 2003, 28; Uwe Siemon-Netto, "Mob Beheads Nun in Bagdad," United Press International, 27 August 2002; Ray J. Mouawad, "Syria and Iraq-Repression: Disappearing Christians of the Middle East," Middle East Quarterly 8, 1 (Winter 2001), http://www.meforum.org/article/17 (accessed 13 October 2006).

254. Michael Mainville, "Armenian Angst; Poverty, Corruption Spur Sense of Powerlessness," Washington Times, 14 September 2005, A15. "An estimated 350,000 Assyrians have migrated to the United States, many of them concentrated in the Turlock-Modesto-Ceres [California] areas and in Detroit and Chicago." "California Assembly Joint Resolution No. 31-Relative to Assyrians in Iraq" (24 April 2003), http:// info.sen.ca.gov/pub/03-04/statute/ch_0051-0100/ch_73_st_2003_ajr_31 (accessed 1 March 2006). 
255. "Iraq, Afghanistan, 11 Other States At Risk of Genocide: Expert," Agence France-Presse, 27 January 2004, http://www.keepmedia.com/pubs/AFP/2004/01/27/361322 (accessed 16 October 2006).

256. Ibid.

257. Tripp, History of Iraq, 79-81; UN Office for the Coordination of Humanitarian Affairs, "Iraq: Focus on Mass Graves," IRIN Middle East, 7 January 2004, http:// www.irinnews.org/report.asp?ReportID=38775\&SelectRegion=Iraq_Crisis\& SelectCountry=IRAQ (accessed 16 October 2006); US Department of State, "Iraq Human Rights Practices, 1994" (February 1995), http://dosfan.lib.uic.edu/ERC/democ racy/1994_hrp_report/94hrp_report_nea/Iraq.html (accessed 16 October 2006); International Federation of Human Rights [FIHR] and Alliance Internationale pour la Justice [AIJ], Iraq: Continuous and Silent Ethnic Cleansing (January 2003), http://www.fidh.org/IMG/pdf/iq350a.pdf (accessed 16 October 2006), 16; Human Rights Watch, "Reversing Ethnic Cleansing in Northern Iraq," Claims in Conflict 16, 4 (August 2004), http://hrw.org/reports/2004/iraq0804 (accessed 16 October 2006); Siemon-Netto, "Attacks Defy"; Ken Joseph, Jr., "Iraq's Secret Documents," Washington Times, 23 July 2004, http://washingtontimes.com/upi-breaking/20040723123038-6416r.htm (accessed 1 March 2006).

258. US Department of State, "Iraq Human Rights Practices."

259. Dr. Katrin Michael, a Chaldean Assyrian who met with President George W. Bush and Vice President Dick Cheney on 14 March 2003, was a victim of the chemical weapons attack on Halabja in 1988. The White House, "News and Policies" (news release, March 2003), http://www.whitehouse.gov/news/releases/2003/03/images/20030314-26_ p27771-07a-515h.html (accessed 16 October 2006); Katrin Michael, "Testimony of Survivor Dr. Katrin Michael [before the US House of Representatives]," 6 March 2003, http:// www.house.gov/kirk/halabja_drmichael_testimony.htm (accessed 16 October 2006); Lewis, "Iraqi Assyrians"; Peter Carlson, "Gassed by Iraqi Troops, Blindsided by the INS: Exile Lends Support to Bush, Then Finds Herself on Immigration's Deportation List," Washington Post, 9 April 2003, C01, http://www.washingtonpost.com/ac2/wp-dyn? pagename $=$ article\&node $=\&$ contentId $=\mathrm{A60181}-2003 \mathrm{Apr} \& \&$ notFound $=$ true $($ accessed 19 October 2006).

260. UK Home Office, "Iraq Country Assessment" (April 2002), http://www.ecoi.net/pub/ nz302_00978irq.htm (accessed 1 March 2006), paras. 6.13, 6.71.

261. FIHR and AIJ, "Iraq: Continuous and Silent," Appendices A, H.

262. Ibid.

263. Ibid.

264. Mordechai Nisan, Minorities in the Middle East: A History of Struggle and Self-Expression (Jefferson, NC: McFarland \& Co., 1991), 166.

265. Lewis, "Iraqi Assyrians."

266. Alastair Bruton, "Christian Sects in Kurdish Lands Dwindle," New York Times, 24 May 1993, A14.

267. Siemon-Netto, "Attacks Defy"; Elena Ryumina. "Assyrians Ring in Year 6750," Moscow Times, 1 April 2000, http://www.themoscowtimes.com/stories/2000/04/01/051.html (accessed 16 October 2006); David Clarke, "Australian Assyrian Community," Legislative Council Papers, New South Wales, 12 May 2004, http://www.parliament. nsw.gov.au/prod/parlment/hansart.nsf/V3Key/LC20040512041 (accessed 16 October 2006), 8846, art. 41.

268. Nina Shea, "Canary in a Coal Mine: Iraq's Future as a Tolerant, Democratic Nation Is at Stake," National Review Online, 14 October 2004, http://www.nationalre view.com/comment/shea200410140830.asp (accessed 16 October 2006). Ethnic cleansing includes not simply the extermination of an ethnic group but also "rendering an area ethnically homogenous by using force or intimidation to remove persons of given groups from the area." Final Report of United Nations Commission of Experts to the Security Council, S/1994/674 (27 May 1994), s. III.B. 
269. UK Home Office, "Iraq Country Assessment," paras. 6.124-6.132; US Department of State, "Iraq: Country Reports on Human Rights Practices-2002" (31 March 2003), http:// www.state.gov/g/drl/rls/hrrpt/2002/18277.htm (accessed 16 October 2006).

270. UKHome Office, "Iraq Country Assessment" (October 2004), http://www.ind.homeoffice. gov.uk/ind/en/home/0/country_information/country_reports.Maincontent.0046.file.tmp/ Iraq\%20October\%202004.pdf (accessed 1 March 2006), para. 6.51.

271. Kenneth Chan, "Christians Wish to Stay, Build Future in Iraq," Christian Post, 21 October 2004, http://www.christianpost.com/article/missions/1169/full/christians.wish. to.stay.build.future.in.iraq/1.htm (accessed 16 October 2006). For similar figures, see "Christians in Iraq Caught in the Crossfire," Associated Press, 11 November 2004.

272. UK Home Office, "Iraq Country Assessment" (2004), para. 6.54; "Seven Christians Shot Dead in Iraq ‘To Arouse Religious Sedition'-Paper,” BBC Monitoring Service, 4 October 2004.

273. UK Home Office, "Iraq Country Assessment" (2004), para. 6.51; William Booth, "For Basra's Liquor Dealers, the Shots Turn Deadly," Washington Post, 1 June 2003, D01.

274. Jonathan Steele, "Kidnappers Find a Profitable Way to Drive Out Educated Families in Baghdad," Guardian (UK), 17 June 2004, http://www.guardian.co.uk/Iraq/Story/ 0,2763,1240571,00.html (accessed 16 October 2006).

275. Simon Caldwell, "Half of All Christians Have Fled Iraq since 2003, Says Baghdad Bishop," Catholic News Service, 3 August 2006, http://www.catholicnews.com/data/stories/cns/ 0604409.htm (accessed 16 October 2006).

276. Jack Fairweather, "Christians Flee Genocide as Fear Sweeps Iraq," Daily Telegraph (London), 1 August 2005, http://www.telegraph.co.uk/news/main.jhtml?xml=/news/2005/ 01/08/wirq08.xml\&sSheet=/news/2005/01/08/ixworld.html (accessed 16 October 2006); Anna Eshoo, "Statement in Support of the Eshoo Amendment to H.R. 2601, the Foreign Relations Authorization Act for FY 2006 and 2007" (20 July 2005), http://www-eshoo. house.gov/news/iraq072005.aspx (accessed 1 March 2006); Patrick McDonnell,

"After Years of Relative Peace, Christians Live in Fear," Los Angeles Times, 14 November 2004, A16; Jim Lobe, "Iraqi Christians Need Protection, Too," Asia Times, 22 October 2004, http://www.atimes.com/atimes/Middle_East/FJ22Ak01.html (accessed 19 October 2006); Chan, "Christians Wish to Stay"; Shea, "Iraq's Future"; Siemon-Netto, "Attacks Defy." See also "Iraqi Christians Seek Better Life in Lebanon," ADNKI, 10 June 2006, http://www.persecution.org/newsite/countrynewssumm.php?country=Iraq (accessed 19 October 2006).

277. Eshoo, "Statement in Support."

278. "Christians in Iraq."

279. As the consul and consul-general of the United States in the Near East for thirty years wrote after World War I, "Christians were armed against their hereditary oppressors and then left to the vengeance of the latter. In general, they were abandoned, as no Christian power desired to offend the Turk, from whom great benefits were expected." George Horton, The Blight of Asia: An Account of the Systematic Extermination of Christian Populations by Mohammedans and of the Culpability of Certain Great Powers; with the True Story of the Burning of Smyrna (Indianapolis: Bobbs-Merrill, 1926), 119. A British lieutenant-colonel and high official in Mesopotamia during and after the war wrote, "[The Assyrians] had twice been betrayed by the Russians, but they still carried on, trusting now to the British. As a reward they have lost their former homes and more than one-third of their original numbers. When it is considered how much the Arabs have gained with infinitely less suffering and loss, it is impossible not to agree with the Assyrians to the extent of admitting they have indeed been unlucky." Stafford, Tragedy of the Assyrians, ch. 2. Sir Percy Cox, British civil commissioner for the British Mandate of Iraq, declared that "The Assyrians ... had been recognised as Allies by Great Britain in the War, and had been used by her in the campaign of 1919 in Kurdistan. A definite promise of settlement under a benevolent, if not a British government, had been made to them," but this promise was never fulfilled. Official Report on 
Iraq Administration: October, 1920-March, 1928, 102, quoted in Stafford, ibid. See also Browne, "Assyrians," 180-83.

280. "Memorandum for Mr. Stettinius from John W. Pehle, Executive Director, the War Refugee Board, Aug. 28, 1944," reprinted in The American Road to Nuremberg: The Documentary Record, 1944-1945 (Stanford, CA: Hoover Institution Press, 1982), 22, quoted in Ida Bostian, “'Speaking about the Destruction of the Armenians': Early Failures in International Criminal Justice and Lessons for Today," ExpressO Preprint Series Paper 1471 (24 July 2006), 46, http://law.bepress.com/expresso/eps/1471.

281. "Contents of the Speech by the Führer to the Chief Commanders and Commanding Generals on the Obersalzberg, Aug. 22, 1939," reprinted in Kevork B. Bardakjian, Hitler and the Armenian Genocide (Cambridge, MA: Zoryan Institute, 1985), 46-48, quoted in Bostian, "Speaking about the Destruction," 36.

282. Joseph Goebbels, The Goebbels Diaries, 1942-1943, trans. Louis P. Lochner (Garden City, NY: Doubleday, 1948), 240, quoted in Bostian, "Speaking about the Destruction," 51.

283. Bass, Stay the Hand of Vengeance, 40, quoted in Bostian, "Speaking about the Destruction," 47-48.

284. See Benjamin A. Valentino, Final Solutions: Mass Killing and Genocide in the Twentieth Century (Ithaca, NY: Cornell University Press, 2004); Adam Jones, ed., Genocide, War Crimes and The West: History and Complicity (London: Zed Books, 2004).

285. Eden Naby, “The Assyrians of Iran: Reunification of a 'Millet,' 1906-1914," International Journal of Middle East Studies 8 (1977): 237-49, 248.

286. See Bruton, "Christian Sects," A14; Sergio Chapa, "Judge Denies Motion by Iraqi Christians: Asylum Seekers Still Have to Serve Six Months in Jail,"

Brownsville Herald, 19 May 2006, http://www.brownsvilleherald.com/ ts_more.php?id=70850_0_10_0_C (accessed 16 October 2006); European Council on Refugees and Exiles, "Guidelines on the Treatment of Iraqi Asylum Seekers and Refugees in Europe," International Journal of Refugee Law 18 (2006): 452-74, http://www.ecre.org/ positions/Iraq06.pdf (accessed 16 October 2006); Government of Australia, Human Rights and Equal Opportunity Commission, "Setting the Scene: Children in Immigration Detention," in A Last Resort? The Report of the National Inquiry on Children in Detention (2004), ch. 3, http://www.hreoc.gov.au/Human_Rights/children_detention_report/report/ chap03.htm (accessed 16 October 2006).

287. In 1961, the General Assembly of the United Nations declared that "all peoples have the right to self-determination," including to "freely determine their political status" and develop their culture and society, and that "subjection of peoples to alien subjugation... constitutes a denial of fundamental human rights [and] is contrary to the Charter of the United Nations." Declaration on the Granting of Independence to Colonial Countries and Peoples, UN General Assembly Resolution 1514, UN Doc. A/4684 (1961), para. 26. In 1975 , the International Court of Justice held that colonized peoples have a right to selfdetermination "through the free and genuine expression of the[ir] will." Western Sahara, advisory opinion of 16 October 1975, ICJ Reports 1975: 12-227, 30. Thus, international law has adopted the right of self-determination "as an operative norm." Richard Falk, "Essay: Problems and Prospects for the Kurdish Struggle for Self-Determination after the End of the Gulf and Cold Wars," Michigan Journal of International Law 15 (1994): 591-603, 598.

288. "It is a principle of international law that the breach of an engagement involves an obligation to make reparation in an adequate form." Federal Republic of Germany $v$. Poland (Case Concerning the Factory at Chorzów), 1927, P.C.I.J., Ser. A, ruling no. 9 on jurisdiction, 21. "Reparation must, as far as possible, wipe out all the consequences of the illegal act and reestablish the situation which would, in all probability, have existed if that act had not been committed. Restitution in kind, or, if this is not possible, payment of a sum corresponding to the value which a restitution in kind would bear; the award, if need be, of damages for loss sustained which would not be covered by restitution in kind or payment in place of it-such are the principles which should serve to determine the 
amount of compensation due for an act contrary to international law." Federal Republic of Germany v. Poland (Case Concerning the Factory at Chorzów), judgment no. 13, 1928, P.C.I.J., Series A, ruling no. 17 on merits, 47. A state, therefore, "has an obligation to compensate, in accordance with the applicable rules of international law, all natural or legal persons having suffered any form of material damage as a result" of a violation by that state of international law. "Legal Consequences of the Construction of a Wall in the Occupied Palestinian Territory" (advisory opinion, International Court of Justice, 9 July 2004), International Legal Materials 43 (2004): 1009-99.

For discussion of further decisions by the International Court of Justice and other tribunals bearing on the obligation to make restitution for violations of international law, see Malcolm N. Shaw, International Law (Cambridge: Cambridge University Press, 2003), 95, 241-42, 694-97, 714-19, 995. American law also recognizes this basic principle. Sosa v. Alvarez-Machain, 542 U.S. 692, 732 (2004) (civil action for damages may exist under US law for serious violations of international law such as torture, piracy, and slavery); Republic of Austria v. Altmann, 541 U.S. 677 (2004) (original owner of paintings by Gustav Klimt had civil action in United States against Austrian museum that gained possession of them in violation of international law due to expropriations by Nazis and Austrian government); D'Amato v. Deutsche Bank, 236 F.3d 78, 2001 (2d Cir. 2001) (approving \$40-million settlement of claims by Holocaust victims and their heirs against Austrian and German banks charged with violations of international law in dealings with Nazis); In re Holocaust Victim Assets Litigation, 225 F.3d 191 (2d Cir. 2000) (approving \$1.25-billion settlement of claims by Jewish, Polish, Roma, and other Holocaust victims against Swiss banks); Kadic v. Karadzic, 70 F.3d 232 (2d Cir. 1995) (genocide, torture, and other violations of international law by Bosnian Serb leader gave rise to tort claims in US courts); "U.S. Involvement in Claims by Victims of the German Holocaust or Their Heirs," American Journal of International Law 93 (1999): 879-92 (describing successful claims by Holocaust victims for reparations under US and international law).

289. Lyden, "Despite Turmoil." The US Commission on International Religious Freedom noted in its 2005 report on Iraq that "reconstruction funds from the United States earmarked for the governorate level were not reaching ChaldoAssyrian villages," so "Christian communities have been uniquely unable to rebuild basic infrastructure in their villages, including water and electrical systems, school facilities, and housing." US Commission on International Religious Freedom [CIRF], Annual Report of the United States Commission on International Religious Freedom (2005), http://www.uscirf.gov/countries/publications/ currentreport/2005annualRpt.pdf (accessed 16 October 2006), 13.

290. "A recent report by European Union Parliament Member Albert Jan Maat says "International aid is mainly distributed through regional and therefore Muslim leaders and seldom or never reaches the Assyrians." Ken Joseph, Jr., "Iraq's Secret Documents," United Press International, 23 July 2004.

291. UN News Centre, "UN War Reparations Body for Iraq Invasion of Kuwait Completes Main Work" (20 June 2005), http://www.un.org/apps/news/story.asp?NewsID=14835\& $\mathrm{Cr}=\mathrm{iraq} \& \mathrm{Cr} 1=$ kuwait (accessed 16 October 2006). "Kuwaiti casualties are estimated to have been light, but specific numbers are unknown." US Department of Defense, Final Report to Congress: Conduct of the Persian Gulf War (April 1992), http://www.au.af.mil/au/ awc/awcgate/gulfreports/titlev.doc (accessed 16 October 2006).

292. US CIRF, Annual Report, 18. The Assyrian American National Federation has proposed $5 \%$ of such funds as a just proportion. Jim Lobe, "Plight of Christians Provokes Calls for Special Protection," Inter Press Service, 20 October 2004, http://64.233.179.104/ search?q=cache:g58M2R8E4TMJ:ipsnews.org/new_nota.asp\%3Fidnews\%3D25948 (accessed 1 March 2006).

293. Samantha Power, "A Problem from Hell": America and the Age of Genocide (New York: HarperCollins, 2002), 47; Barry A. Fisher, "No Roads Lead to Rom: The Fate of the Romani 
People under the Nazis and in Post-War Restitution," Whittier Law Review 20 (1999): 513-47.

294. For a fairly comprehensive account of this pattern in Nazi-occupied Europe, see Shirer, Rise and Fall, 872-78, 1223-92.

295. Bloxham, "Armenian Genocide," 189; William A. Schabas, "Darfur and the "Odious Scourge': The Commission of Inquiry's Findings on Genocide," Leiden Journal of International Law 18 (2005): 871-85, 875.

296. In the $1850 \mathrm{~s}$, Britain actually committed military forces during the Crimean War, thereby defending the Ottoman Empire against a Russian campaign to protect the Ottoman Christians. Sneh Mahajan, British Foreign Policy, 1874-1914: The Role of India (London: Routledge, 2002), 27; Robert B. Edgerton, Death or Glory: The Legacy of the Crimean War (Boulder, CO: Westview Press, 1999), 12-13. The Crimean War "was due mainly to the efforts of the Czar Nicholas to extend his protection over the Greek Christians in Turkey." John Holland Rose, The Development of the European Nations, 1870-1914, 5th ed. (New York: G.P. Putnam's Sons, 1915), http://www.gutenberg.org/files/14644/14644-h/ 14644-h.htm (accessed 16 October 2006), 161. On an uncharitable view, Britain and France entered the fray on the side of the Ottoman Empire because they "wished to play a great part in the world" and "resented the encroachments of Russia in the East." Ibid.

297. Frederick Jones Bliss, “The Ottoman Empire, 1801-1913 [Review]," American Historical Review 19 (1914): 355-56.

298. Suha Bolukbasi, "Behind the Turkish-Israeli Alliance: A Turkish View," Journal of Palestine Studies 29 (1999): 101-15. In the 1950s and 1960s, Turkish violence and persecution against Greek Christians, the forcible deportation of Greek citizens, and the expropriation of their property contributed to driving an estimated $97 \%$ of Greeks in Turkey, more than 95,000 people, to flee. Steven Stavros Skenderis, "Note and Comment: The Ethnic Greeks of Turkey: The Present Situation of the Greek Minority and Turkey's Human Rights Obligations Under International Law," St. Thomas Law Review 16 (2004): 551-94, 564-65, citing Human Rights Watch, Denying Human Rights and Ethnic Identity: The Greeks of Turkey (New York: HRW, 1992), 7-9, and Loucas Tsilas, "Greek-Turkish Relations in the Post-Cold War Era," Fordham International Law Journal 20 (1997): 1589-1605, 1599-1600. Starting in 1974, Turkey invaded and began illegally occupying and colonizing northern Cyprus. Tsilas, "Greek-Turkish Relations," 1603-5.

299. As for Turkey, the US Congress has debated whether continuing to provide aid to Turkey is to turn a blind eye to its persecution of Christians and Kurds, its blockade of Armenia, and its occupation of northern Cyprus. "House Tables Foreign Aid Bill," United Press International, 6 June 1996; "Prepared Statement of Eugene T. Rossides on Behalf of the American Hellenic Institute Public Affairs Committee, Inc., et al., before the House Appropriations Committee, Subcommittee on Foreign Operations, Export Financing and Related Programs" (25 April 1996). As for Iraq, the Reagan and George H.W. Bush administrations offered critical military and financial aid to Iraq after it had embarked upon campaigns of "Arabization" and ethnic cleansing in northern Iraq, in which the Assyrians and other Christians were caught up. Lewis M. Simons, "Genocide and the Science of Proof," National Geographic, January 2006: 28-32, 32; Craig Unger, House of Bush, House of Saud: The Secret Relationship Between the World's Two Most Powerful Dynasties (New York: Scribner, 2004), 75-82; Christopher Marquis, "Rumsfeld Made Iraq Overture in '84 Despite Chemical Raids," New York Times, 23 December 2003, http:// www.nytimes.com/2003/12/23/international/middleeast/23RUMS.html?ei=5007\& en $=$ e34fa9fa 4 ca4e33c\&ex $=1387515600 \&$ partner $=$ USERLAND\& pagewanted $=$ print\&position $=($ accessed 16 October 2006); Joost R. Hiltermann, "Halabja: America Didn't Seem to Mind Poison Gas," International Herald Tribune, 17 January 2003, http://www.iht.com/articles/2003/01/17/edjoost_ed3_.php (accessed 16 October 2006); Tim Reid, "How US Helped Iraq Build Deadly Arsenal," Times (London), 31 December 2002. 
300. Burak Ege Bekdil and Umit Enginsoy, "European Firms Eye Boost in Turk Business under EU,” Defense News, 24 October 2005, 26; “Turkey Rejects U.S. Aid Loan,” Washington Post, 7 June 1996, A28; James Morrison, "Embassy Row," Washington Times, 20 February 1995, A14; Martin Sieff, "Dole Targets Nations That Impede U.S. Aid," Washington Times, 13 January 1995, A15; “Turkey Moves Troops to Armenian Border," New York Times, 4 September 1993, 1-5.

301. See Oles M. Smolansky, The USSR and Iraq: The Soviet Quest for Influence (Durham, NC: Duke University Press, 1991), 230-80; “The Soviet Union," in Metz, Iraq: A Country Study, http://countrystudies.us/iraq/82.htm (accessed 16 October 2006); "Arms from the Soviet Union," in Metz, Iraq: A Country Study, http://countrystudies.us/iraq/98.htm (accessed 16 October 2006).

302. Walid Phares, "Are Christian Enclaves the Solution?" Middle East Quarterly 8 (2001), http://www.meforum.org/article/18.

303. Ibid.; Bernard Reich and Stephen H. Gotowicki, "The United States and the Persian Gulf in the Bush Administration," Royal United Services Institute and Brassey's Defense Yearbook (1991), http://fmso.leavenworth.army.mil/documents/usgulf.htm (accessed 16 October 2006); "Keeping the Peace: Operation Joint Endeavor, Bosnia," Airman, January 1997, http://www.af.mil/news/airman/0197/bosnia.htm (accessed 16 October 2006); Robert Tomes, "Operation Allied Force and the Legal Basis for Humanitarian Interventions," Parameters, Spring 2000, 38-50, http://www.carlisle.army.mil/USAWC/ PARAMETERS/00spring/tomes.htm (accessed 16 October 2006).

304. Fairweather, "Christians Flee Genocide."

305. Millard Burr, Quantifying Genocide in Southern Sudan and the Nuba Mountains, 1983-1998 (US Committee for Refugees, December 1998), 25; US Department of State, 1999 Country Reports on Human Rights Practices: Sudan (25 February 2000), http:// www.state.gov/www/global/human_rights/1999_hrp_report/sudan.html (accessed 16 October 2006); US Department of State, Bureau of Democracy, Human Rights, and Labor, "International Religious Freedom Report 2004: Sudan" (15 September 2004), http://www.state.gov/g/drl/rls/irf/2004/35384.htm (accessed 16 October 2006); Caroline Davies, "Khartoum's 'Holy War' against Christians Turns into Bloody Genocide," Daily Telegraph (London), 26 May 1998; Princeton N. Lyman, "Editorial: Nigeria Burns for Islam," Wall Street Journal, 27 November 2002, A10; Dulue Mbachu, "Sectarian Mobs in Nigeria Kill 24," Boston Globe, 21 February 2006, http://www.boston.com/news/world/ africa/articles/2006/02/21/sectarian_mobs_in_nigeria_kill_24 (accessed 16 October 2006); "Violence Left 3 Million Bereft in Past 7 Years, Nigeria Reports," New York Times, 14 March 2006, http://www.nytimes.com/2006/03/14/international/africa/ 14nigeria.html (accessed 1 March 2006). 


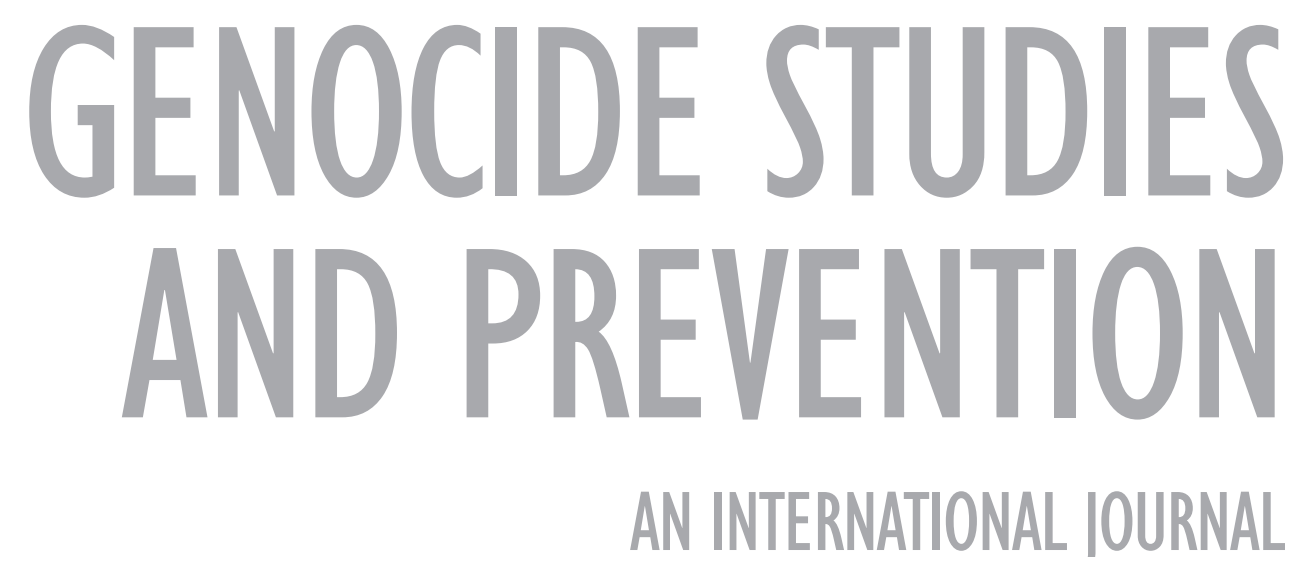

